\title{
Examining the Impact of Nitrous Acid Chemistry on Ozone and PM over the Pearl River Delta Region
}

\author{
Rui Zhang, ${ }^{1}$ Golam Sarwar, ${ }^{2}$ Jimmy C. H. Fung, ${ }^{1,3}$ Alexis K. H. Lau, ${ }^{3}$ and Yuanhang Zhang ${ }^{4}$ \\ ${ }^{1}$ Department of Mathematics, The Hong Kong University of Science \& Technology, Clear Water Bay, Kowloon, Hong Kong \\ ${ }^{2}$ Atmospheric Modeling and Analysis Division, National Exposure Research Laboratory, Office of Research and Development, \\ US Environmental Protection Agency, RTP, NC 27711, USA \\ ${ }^{3}$ Division of Environment, The Hong Kong University of Science \& Technology, Clear Water Bay, Kowloon, Hong Kong \\ ${ }^{4}$ College of Environmental Sciences and Engineering, Peking University, Beijing 100871, China
}

Correspondence should be addressed to Golam Sarwar, sarwar.golam@epa.gov and Jimmy C. H. Fung, majfung@ust.hk

Received 16 February 2012; Accepted 3 April 2012

Academic Editor: Tareq Hussein

Copyright ( 2012 Rui Zhang et al. This is an open access article distributed under the Creative Commons Attribution License, which permits unrestricted use, distribution, and reproduction in any medium, provided the original work is properly cited.

\begin{abstract}
The impact of nitrous acid (HONO) chemistry on regional ozone and particulate matter in Pearl River Delta region was investigated using the community multiscale air quality (CMAQ) modeling system and the CB05 mechanism. Model simulations were conducted for a ten-day period in October 2004. Compared with available observed data, the model performance for $\mathrm{NO}_{x}$, $\mathrm{SO}_{2}, \mathrm{PM}_{10}$, and sulfate is reasonably good; however, predictions of $\mathrm{HONO}$ are an order of magnitude lower than observed data. The CB05 mechanism contains several homogenous reactions related to HONO. To improve the model performance for HONO, direct emissions, two heterogeneous reactions, and two surface photolysis reactions were incorporated into the model. The inclusion of the additional formation pathways significantly improved simulated HONO compared with observed data. The addition of HONO sources enhances daily maximum 8 -hour ozone by up to $6 \mathrm{ppbV}(8 \%)$ and daily mean $\mathrm{PM}_{2.5}$ by up to $17 \mathrm{ug} / \mathrm{m}^{3}(12 \%)$. They also affected ozone control strategy in Pearl River Delta region.
\end{abstract}

\section{Introduction}

The importance of nitrous acid (HONO) to tropospheric chemistry is well recognized due to its contribution to $\mathrm{HO}_{x}$ $\left(\mathrm{OH}+\mathrm{HO}_{2}\right)$ budget, which may lead to the enhancement of overall oxidation capacity of the atmosphere [1-10]. Accumulated $\mathrm{HONO}$ at night would undergo photolysis after sunrise to become an important source of hydroxyl radical $(\mathrm{OH})$. It is especially important in the early morning when other major $\mathrm{OH}$ sources are still small.

$$
\mathrm{HONO}+h \nu(300 \mathrm{~nm}<\lambda<400 \mathrm{~nm}) \longrightarrow \mathrm{OH}+\mathrm{NO}
$$

Analysis of measured HONO in urban area of Europe suggested that reaction (R1) contributes more than 30\% of the integrated photolytic $\mathrm{HO}_{x}$ formation $[6,7]$. Some recent studies even suggested its significance through the entire day especially over the remote environment $[9,11-13]$. Box model studies by considering the importance of $\mathrm{HONO}$ photolysis to $\mathrm{HO}_{x}$ budget also demonstrated its impact on $\mathrm{O}_{3}$ buildup $[1,2]$.

Despite the importance of HONO to tropospheric chemistry, the detail formation mechanisms, especially during daytime, have not been well established yet and incorporated into air quality models. There exist some review papers [14-16] to summarize the current knowledge on HONO formation mechanisms. Normally, four groups of HONO formation pathways were indentified: direct emission, homogeneous reactions, heterogeneous reactions, and surface photolysis reactions.

HONO can be directly emitted into the atmosphere via combustion process (e.g., vehicle exhaust) when temperature of produced NO (from nitrogen thermal fixation) is decreased [14]. Measurements of HONO emission from combustion system are mainly focused on motor vehicles, especially diesel vehicles. $\mathrm{HONO} / \mathrm{NO}_{x}$ emission ratio from different engines was reported on average to be $0.3 \sim 0.8 \%$ [19-21]. Direct HONO emission source can possibly play an 
important role over heavily polluted areas with high traffic volume.

The most important homogeneous reaction that produces HONO is the reverse reaction of (R1) [16]:

$$
\mathrm{OH}+\mathrm{NO}+\mathrm{M} \longrightarrow \mathrm{HONO}+\mathrm{M}
$$

This reaction has a greater role during daytime when the mixing ratios of $\mathrm{OH}$ and $\mathrm{NO}$ are high, and little contribution to the HONO was built up at night. The excited $\mathrm{NO}_{2}\left(\mathrm{NO}_{2} \mathrm{E}\right)$ chemistry is another homogenous reaction that can produce HONO in urban areas [22-26]:

$$
\mathrm{NO}_{2} \mathrm{E}+\mathrm{H}_{2} \mathrm{O} \longrightarrow \mathrm{OH}+\mathrm{HONO}
$$

Also, carbon bond 2005 (CB05) chemical mechanism [27] contains the following homogenous reactions which are considered small impacts to HONO formation:

$$
\begin{gathered}
\mathrm{NO}+\mathrm{NO}_{2}+\mathrm{H}_{2} \mathrm{O} \longrightarrow 2.0 \mathrm{HONO} \\
\mathrm{HONO}+\mathrm{HONO} \longrightarrow \mathrm{NO}+\mathrm{NO}_{2}+\mathrm{H}_{2} \mathrm{O} \\
\mathrm{OH}+\mathrm{HONO} \longrightarrow \mathrm{NO}_{2}+\mathrm{H}_{2} \mathrm{O}
\end{gathered}
$$

Recently, the photolysis of aromatic compounds containing the ortho-nitrophenol was proposed as a new gas-phase source of HONO, which would partially help to explain the high contribution of HONO to oxidation capacity in urban atmosphere environment [28].

Most chamber studies indicated the importance of $\mathrm{HONO}$ production through the heterogeneous conversion of $\mathrm{NO}_{2}$ absorbed on the available surfaces in the presence of water vapor $[14,29]$ :

$$
\begin{array}{r}
\mathrm{NO}+\mathrm{NO}_{2}+\mathrm{H}_{2} \mathrm{O}(\text { surface }) \longrightarrow 2 \mathrm{HONO} \\
2 \mathrm{NO}_{2}+\mathrm{H}_{2} \mathrm{O}(\text { surface }) \longrightarrow \mathrm{HONO}+\mathrm{HNO}_{3}
\end{array}
$$

The heterogeneous nature of those reactions was shown by the enhanced conversion frequency with the increase of $S / V$ ratio and the strong dependence on surface properties [3032]. HONO heterogeneous production can also appear either on soot or on semiorganic surface $[33,34]$ :

$$
\mathrm{NO}_{2}+\text { reduced surface } \longrightarrow \mathrm{HONO}+\text { oxidized surface }
$$

However, the surface deactivation occurs on soot within a few minutes, and consequently, it is not an important pathway for $\mathrm{HONO}[35,36]$. In regards to the reaction on semiorganic surface, even though the potential to HONO production is relatively high [18], the parameterization method is still open to discuss. Besides those, the renoxification of $\mathrm{HNO}_{3}$ on surfaces was also believed to be important for HONO formation within the boundary layer of polluted atmosphere [37, 38]:

$$
\mathrm{NO}+\mathrm{HNO}_{3}(\text { surface }) \longrightarrow \mathrm{NO}_{2}+\mathrm{HONO}
$$

With the involvement of solar radiation, two surface photolysis reactions are believed to be important for daytime
HONO formation. One is the photosensitized reduction of $\mathrm{NO}_{2}$ on organic surface $[39,40]$ :

$$
\mathrm{NO}_{2}+A_{\text {red }}(\text { surface })+h \nu \longrightarrow \mathrm{HONO}+A^{\prime \prime}
$$

where $A_{\text {red }}$ is the reduced photosensitizer in aromatic hydrocarbons or humid acids. The other one is the photolysis of absorbed nitric acid $\left(\mathrm{HNO}_{3}\right)$ deposited on the ground [41, 42]:

$$
\mathrm{HNO}_{3}+h v \longrightarrow 0.5 \mathrm{HONO}+0.5 \mathrm{NO}_{2}
$$

Recently, the enhancement of $\mathrm{NO}_{2}$ to $\mathrm{HONO}$ conversion on soot particles with the presence of artificial solar radiation was also proposed as a potential pathway for HONO formation [43].

There are already some modeling attempts to test the impact of different HONO formation pathways to photochemistry using either box model $[17,44]$ or 3D air quality model [18, 45-47]. For example, Aumont et al. [17] demonstrated the importance of direct emission and heterogeneous reactions to HONO enhancement under polluted condition using two-layer box model. Vogel et al. [44] suggested that reaction (R8) and emission were the most important sources of night time HONO production using a one-dimensional air quality model. Lei et al. [45] reported that reaction (R8) enhanced daytime $\mathrm{OH}$ and subsequently increased daytime $\mathrm{O}_{3}$ by $4-12$ ppbV by using a $3 \mathrm{D}$ chemical transport model in Houston. Sarwar et al. [46] incorporated reaction (R8), (R12), and direct HONO emission into CMAQ model and reproduced $60 \%$ observed $\mathrm{HONO}$ value at eastern US. Li et al. [18] pointed out that reaction (R8) and (R9) can significantly improve $\mathrm{HO}_{x}$ simulations during daytime and the partition of $\mathrm{NO} / \mathrm{NO}_{2}$ in the morning in Mexico using WRFCHEM model. Gonçalves et al. [47] applied the WRF-CMAQ modeling system to quantify the contribution of $\mathrm{HONO}$ direct emission and reaction (R8) on predicted $\mathrm{O}_{3}$ and $\mathrm{PM}_{2.5}$ value. However, most of the studies were carried out over relatively clean area with moderate photochemical precursor level. Evaluating the impact of additional HONO sources to air quality over heavy-polluted areas such as Pearl River Delta region, China has important practical significance.

Measurements in $\mathrm{PRD}$ region indicate the presence of elevated ambient HONO levels not only in urban but also in rural areas. For example, early-morning $\mathrm{HONO}$ mixing ratio of up to $12 \mathrm{ppbV}$ was measured at Guangzhou (GZ) in June 2000 [48]. Mean noon value of about $4 \mathrm{ppbV}$ at GZ was measured during the first Program of Regional Integrated Experiments on air quality over the PRD in October, 2004 (PRIDE-PRD2004 [49]). A nocturnal peak HONO mixing ratio of over $8 \mathrm{ppbV}$ was reported in PRIDE-PRD2006 campaign $[50,51]$. High nighttime HONO levels of up to $4 \mathrm{ppbV}$ [52] occurred even at the rural site Xinken (XK), which is located at the western coast of Pearl River Estuary (PRE) (see Figure 1).

Observation based-model (OBM) also supported the importance of HONO chemistry to the PRD region especially during the episode days. Zhang et al. [8] used the observed HONO data at XK as input to GIT-OBM model 


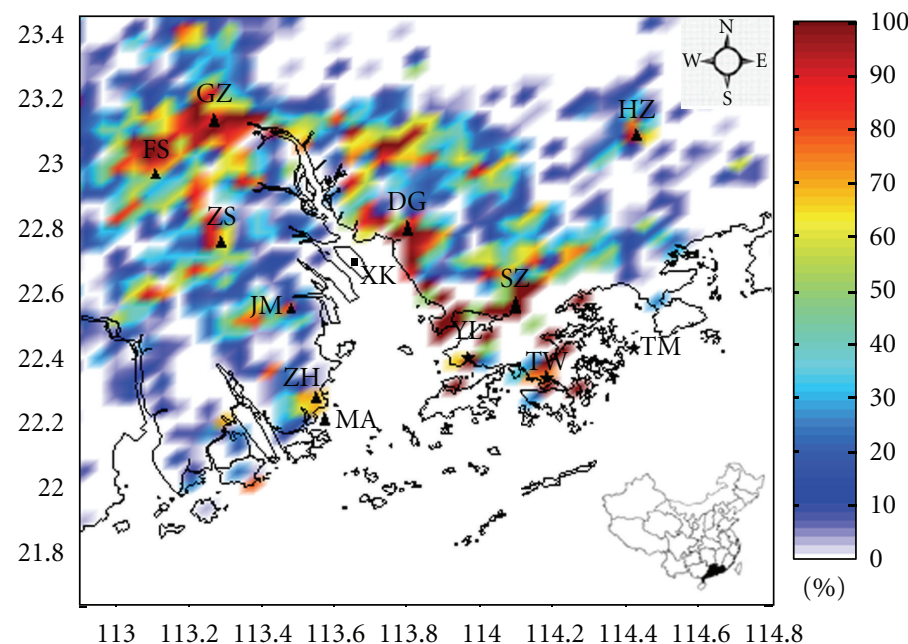

FIGURE 1: The geographic coverage of CMAQ model overlapped with urban density fraction (scaled from 0\% to 100\%) over Pearl River Delta region, China. $\boldsymbol{\Delta}$ represents the locations of urban cities over this region, in which the star sites Yuen Long (YL), Tsuen Wan (TW) and Tap Mum (TM) are there ambient air quality monitoring stations in Hong Kong with hourly continuous observation data for criteria pollutants. represents the location of Xinken (XK) site.

and compared simulation results to those obtained with gasphase HONO chemistry only. Two-to-four times increase of $\mathrm{OH}$ and ozone production rate were found both at $\mathrm{GZ}$ or XK site, which may suggest the importance of heterogeneous reactions of HONO to regional photochemical process. Lu et al. [53] employed the same model to investigate the importance of HONO during the PRIDE_PRD2006 campaign. It was suggested that it is one of the critical species for radical recycling and photochemical $\mathrm{O}_{3}$ production for the urban areas.

Currently, CMAQ model only considers homogeneous formation pathway for HONO; hence, it may underestimate HONO level by order of magnitude [46]. The additional HONO sources can produce more $\mathrm{OH}$ and may improve model performance for $\mathrm{O}_{3}$ and PM. In this study, direct HONO emissions and four additional HONO formation pathways were incorporated into CMAQ model, and their effects on predicted $\mathrm{HONO}, \mathrm{O}_{3}$, and $\mathrm{PM}$ were investigated over PRD region.

\section{Methodology}

2.1. Model Description. CMAQ version 4.6 [54] was used for this study. Modeling domain was shown in Figure 1 and consisted of $49 \times 49$ grid cells with 4.5 kilometer grid spacing. The boundary conditions of the domain of interest were provided by the outer nesting domains and kept consistent for different case run. Twenty vertical layers were constructed in CMAQ with the first layer around $17 \mathrm{~m}$ above the ground and 11 vertical layers below $1 \mathrm{~km}$. The CB05 gas-phase chemical mechanism [27] was used. The calculation of convective cloud mixing in the planetary boundary layer was represented by Asymmetric Convection Model [55]. The aerosol process was represented by fourth-generation CMAQ aerosol module (AERO4), which includes SORGAM [56] as a secondary organic aerosol model, ISORROPIA [57] as an inorganic aerosol model, and RPM [58] as a regional particulate model. Boundary conditions for the model were generated from the CMAQ results of larger domain covering the southern China. Initial conditions for the model were chosen from default mixing ratio profiles and the first 3-day simulation was used as model spin-up.

The meteorological field for the CMAQ model was simulated by the Fifth-Generation National Center of Atmospheric Research/Pennsylvania State University (NCAR/PSU) Mesoscale Model (MM5) version 3.6.3 [59] with updated land use information and four-dimensional data assimilation (FDDA). Detailed descriptions on model configuration and data preprocessing can be found in Yim et al. [60]. Pervious comprehensive model performance evaluations by comparing the modeled pressure, ground temperature, wind speed, wind direction, and RH with available global telecommunication system observations had demonstrated that this set of MM5 simulation can represent the regional flow pattern reasonably well [60-62] and is suitable for driving chemical transport model for regional air quality study $[63,64]$.

2.2. Emissions for the Model. PRD local emission inventory developed by "bottom-up" methods was allocated into domain grids by Sparse Matrix Operator Kernel Emissions (SMOKE V2.1) [65] through spatial surrogate file, temporal profiles, and chemical speciation profiles [66]. Due to lack of systematic work on local PM and VOC speciation profiles for different sources in China, the corresponding SPECIATE algorithm [67] was introduced to apportion VOC to $\mathrm{CB} 05$ species. Gridded biogenic emission was generated through SMOKE by using the Biogenic Emission Inventory System, version 2 (BEIS2) with emission factors and the land cover information provided by the Hong Kong Planning Department [64]. 


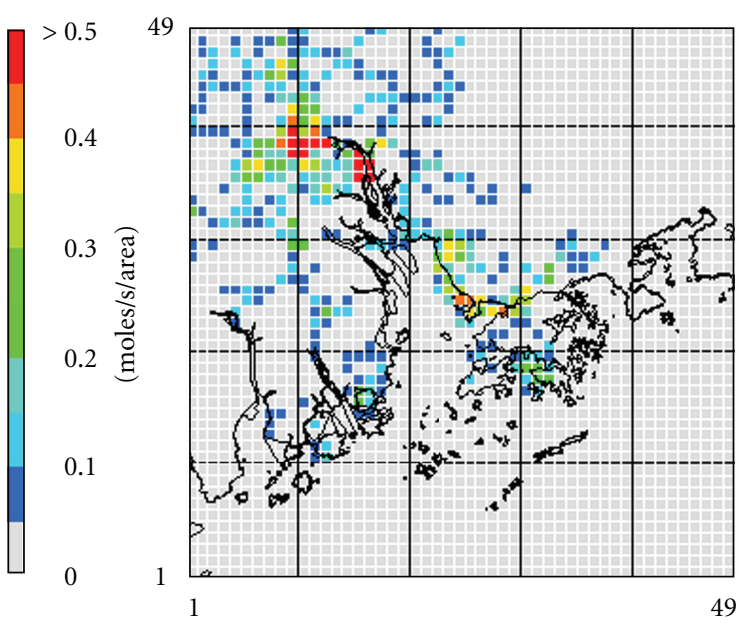

(a)

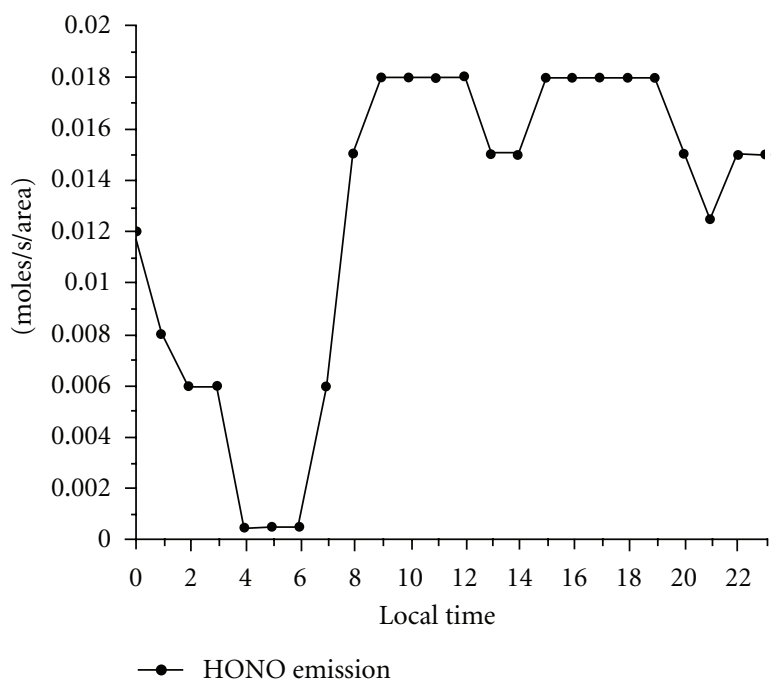

(b)

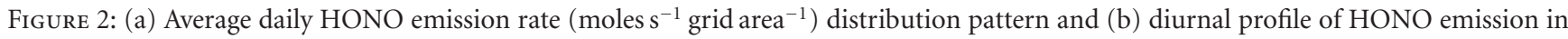
the PRD region.

2.3. HONO Formation Pathways. The CB05 gas-phase chemical mechanism in CMAQ model contains known homogeneous reactions involving $\mathrm{HONO}$ except the excited $\mathrm{NO}_{2}$ chemistry and the photolysis of ortho-nitrophenols [28]. Reaction (R3) is not included in this study since Sarwar et al. [23] reported that it contributes only a small amount to daytime HONO. CMAQ version 4.6 does not contain any direct $\mathrm{HONO}$ emissions from vehicles. In this study, direct HONO emissions are also included. Three groups of additional HONO formation pathways as described earlier were incorporated into CMAQ model. Compared to the similar study of Sarwar et al. [46], reactions (R11) and (R12) are the first time to incorporate into a 3D air quality model for quantifying the HONO impact on air quality modeling results.

Direct HONO emission over PRD region is estimated from on-road and off-road vehicle sources as a fraction of $\mathrm{NO}_{x}$ vehicle emission; $\mathrm{HONO} / \mathrm{NO}_{x}$ emission ratio is set to 0.008 based on the results reported by Kurtenbach et al. [20] Vehicle $\mathrm{NO}_{x}$ emission was initially speciated into NO by $90 \%$ and $\mathrm{NO}_{2}$ by $10 \%$ (by volume). For this study, we modified the speciation of vehicle $\mathrm{NO}_{x}$ emission into $\mathrm{NO}$ by $90 \%, \mathrm{NO}_{2}$ by $9.2 \%$, and $\mathrm{HONO}$ by $0.8 \%$. Su et al. [52] reported an upper limit of 0.01 for [HONO]/[ $\left.\mathrm{NO}_{x}\right]$ ratio in $\mathrm{PRD}$, which is consistent with the value used in this study

$$
E_{\mathrm{HONO}}=0.008 * E_{\mathrm{NO}_{x}}
$$

Estimates of direct $\mathrm{HONO}$ and other emissions were developed using SMOKE [65]. The spatial distribution as well as temporal profile of ground $\mathrm{HONO}$ emission rate is demonstrated in Figure 2. The general HONO distribution pattern matches with PRD road network, and the emission rate is scaled by total vehicle volume. Multiple hotspots with the average daily emission rate greater than $0.5 \mathrm{~mol} \mathrm{~s}^{-1}$ area $^{-1}$ (area in this study is $4.5 \mathrm{~km} \times 4.5 \mathrm{~km}$ ) are found at GZ city and its vicinity area, Dongguan, Shenzhen city cluster, and Central in Hong Kong. The emission gradient between eastern and the western parts of PRE is noticeable. The diurnal variation of HONO emission rate closely follows the vehicle use pattern. Emission rates are relatively high during daytime (08:00-19:00 LST), then drop after the midnight (00:00 LST), and increase again around 07:00 LST with the start of morning rush hour.

Two heterogeneous reactions (R8) and (R10) were added to the CMAQ model. The first-order reaction constant $k_{\mathrm{HONO}}$ is given as

$$
k_{\mathrm{HONO}}=\frac{\gamma_{\mathrm{rxn}} \times[S / V] \times \omega}{4},
$$

where $\gamma_{\mathrm{rxn}}$ is dimensionless reactive uptake coefficient. The $\gamma_{\text {rxn }}$ for reaction (R8) is taken as $1.0 \times 10^{-6}$ [17] and for reaction $(\mathrm{R} 10)$ is taken as $1.0 \times 10^{-8}$ [37]; $\omega$ is the mean thermal velocity of a given reactant and is calculated following Pleim and Xiu [68].

The estimation of $S / V$ for heterogeneous reactions is a challenging task. Total $S / V$ ratio for reaction (R8) includes model-resolved aerosol surface area and other available surface area at the first model layer:

$$
\begin{aligned}
{\left[\frac{S}{V}\right]_{\text {surface }}=} & {\left[\frac{S}{V}\right]_{\text {aerosol }}+\left[\frac{S}{V}\right]_{\text {ground }} } \\
= & {\left[\frac{S}{V}\right]_{\text {aerosol }} } \\
& +\left(2 \times \frac{\text { LAI }}{z_{S}}+\left[\frac{S}{V}\right]_{\text {building }}+\left[\frac{S}{V}\right]_{\text {soil }}\right) .
\end{aligned}
$$

Here, $S / V$ for building is taken to represent surface areas provided by buildings, roads, parking lots, and other structures. Unless during heavily polluted days, the $S / V$ ratio for aerosol is much smaller than corresponding $S / V$ 
values for available surface on the ground [46]. $S / V$ ratio for vegetation can be represented by leaf area index (LAI) in the first model layer $z_{s}$. The LAI values were multiplied by two to account for both sides of leaves into total reaction interface [69]. The $S / V$ ratio for soil is set to $0.1 \mathrm{~m}^{-1}$. Svensson et al. [29] studied the kinetics of the reaction involving $\mathrm{NO}_{2}$ and $\mathrm{H}_{2} \mathrm{O}$ and suggested an $S / V$ value of $0.2 \mathrm{~m}^{-1}$ for typical urban environment. However, Cai [70] used a value of $1.0 \mathrm{~m}^{-1}$ to represent the high urban density environment in New York. In this study, the estimated $S / V$ ratio for building at each grid is taken as proportional to the model-resolved urban fraction (PURB, with the range $10 \%$ to $100 \%$, see Figure 1) and capped with an empirical upper limit $s_{\max }$. Over the very low urban density place with PURB less than $10 \%, S / V$ for building is a fixed value as $10 \%$ of $s_{\max }$ :

$$
\begin{aligned}
& {\left[\frac{S}{V}\right]_{\text {building }}} \\
& \quad= \begin{cases}s_{\max } \times \frac{10}{100}=\frac{s_{\max }}{10} & \text { if PURB }<10 \%, \\
s_{\max } \times \frac{\mathrm{PURB}}{100} & \text { if } 10 \%<\mathrm{PURB}<100 \%,\end{cases}
\end{aligned}
$$

where $s_{\max }=0.3 \mathrm{~m}^{-1}$ is used for the base case following Sarwar et al. [46]. Sensitivity study is also conducted to investigate the impact of alternative value of $s_{\max }$ on predicted HONO. Values of $S / V$ for building over water were set to zero. In the model, reaction (R8) can produce HONO on aerosol surfaces at all vertical levels, while it can only produce HONO in the first layer on ground surfaces.

For renoxification of nitric acid (reaction (R10)), only the $S / V$ on the ground surface is considered. In the model, production of HONO from reaction (R10) can only occur in the first layer.

Two surface photolysis pathways (reactions (R11) and (R12)) for HONO formation are added into CMAQ to investigate the production of $\mathrm{HONO}$ during daytime. As regards to the photosensitized reduction of $\mathrm{NO}_{2}$ on humic acid coated aerosol (reaction (R11)), HONO production is not linearly increased with the integrated actinic flux $F$ (photons $\cdot \mathrm{m}^{-2} \mathrm{~s}^{-1}, 300-750 \mathrm{~nm}$ ) due to the quick deactivation process by reaction with photo-oxidants which are formed simultaneously during the irradiation of humic acid surfaces [39]. In this study, the empirical first-order HONO formation model suggested by Stemmler et al. [40] is parameterized into CMAQ with the uptake coefficient $\left.\gamma_{\mathrm{rxn}}\right|_{\mathrm{HA}}$ :

$$
\left.\gamma_{\mathrm{rxn}}\right|_{\mathrm{HA}}=\frac{4}{\omega} \times \frac{1}{9.3 \times 10^{22} \times\left[\mathrm{NO}_{2}\right] \times[F]^{-1}+2330},
$$

where mixing ratios of $\mathrm{NO}_{2}$ is in ppbV. Only the $S / V$ ratio for soil is considered for reaction (R11). In the model, HONO production from reaction (R11) is released in the first layer only.

$\mathrm{HONO}$ formation through photolysis of absorbed $\mathrm{HNO}_{3}$ on surfaces (reaction (R12)) was incorporated into the model upon the empirical relationship derived from laboratory measurements [71]

$$
\frac{d[\mathrm{HONO}]}{d t}=\frac{\left\{\alpha \times J_{\mathrm{HNO}_{3}}^{*} \times\left. V_{d}\right|_{\mathrm{HNO}_{3}} \times\left[\mathrm{HNO}_{3}\right] \times \Delta t\right\}}{z_{s}},
$$

where $\alpha$ is the fraction of deposited $\mathrm{HNO}_{3}$ exposure to full noontime sunlight with the photolysis rate $J_{\mathrm{HNO}_{3}}$. In this study, $\alpha$ is set as $0.5 .\left.V_{d}\right|_{\mathrm{HNO}_{3}}$ is dry deposition velocity of $\mathrm{HNO}_{3},\left[\mathrm{HNO}_{3}\right]$ is the mixing ratio in the first model layer, $\Delta t$ is accumulated time since the last precipitation event, and $z_{s}$ is the first layer model height $(17 \mathrm{~m})$ in CMAQ configuration. The model assumes that the wet deposition removes all absorbed $\mathrm{HNO}_{3}$ on the ground and resets it to zero for subsequent simulation. The photolysis rate of adsorbed $\mathrm{HNO}_{3}$ reported by Zhou et al. [71] is 24 times greater than the photolysis rate of gaseous $\mathrm{HNO}_{3}$; thus, it was taken as $J_{\mathrm{HNO}_{3}}^{*}=24 \times J_{\mathrm{HNO}_{3}}$ in the model, and $\mathrm{HONO}$ production from reaction (R12) is released in the first layer only.

2.4. General Synoptic Condition and Case Selection. The time period for HONO simulation over PRD region is chosen from 23 October, 2004 to 2 November, 2004, when the PRIDE-PRD2004 campaign was carried out. HONO measurements were conducted using rotated wet effluent diffusion denuder (WEDD) methods at two supersites: one at an urban area $\left(\mathrm{GZ}: 23.13^{\circ} \mathrm{N}, 113.26^{\circ} \mathrm{E}\right)$ and one at a rural area $\left(\mathrm{XK}: 22.61^{\circ} \mathrm{N}, 113.59^{\circ} \mathrm{E}\right.$ ) (Figure 1) [49]. During the PRIDE-PRD2004 campaign period, the persistent surface high-pressure system (anticyclone), descent motion outside of hurricane, and frequent sea breeze result in high-level ground mixing ratio for gaseous and particulate pollutants [72]. For instance, at XK supersite, at least two severe episodes were observed on October 25 and October 29 with measured daily peak $\mathrm{O}_{3}$ mixing ratio reaching over $150 \mathrm{ppbV}$ and $\mathrm{PM}_{2.5}$ peak mixing ratio near or greater than $200 \mu \mathrm{g} / \mathrm{m}^{3}$ [49]. Observed maximum HONO mixing ratio in XK was reported to be more than $4 \mathrm{ppbV}$ in the nighttime and about 1 ppbV during the daytime [52].

A total of eleven simulation cases were performed to investigate the impact of additional HONO formation pathways on air quality modeling results over PRD region. Sensitivity runs were designed to understand the impacts of uncertainties of selected parameters on air quality. Selected significance test on HONO prediction using the previous proposed parameterization methods was carried out to discuss their robustness over PRD region simulation. The impact of HONO chemistry on $\mathrm{O}_{3}$ control strategy due to the VOC emission reduction was also evaluated. The case ID, case description, and designed purpose are summarized in Table 1.

\section{Results and Discussion}

3.1. Model Performance for Base Case CB05. Time series of predicted $\mathrm{SO}_{2}, \mathrm{NO}_{x}, \mathrm{O}_{3}$, and $\mathrm{PM}_{2.5}$, as well as aerosol sulfate and aerosol nitrate (case CB05, see Table 1) are compared 
TABLE 1: Design of CMAQ simulation case to evaluate the HONO chemistry.

\begin{tabular}{|c|c|c|}
\hline Case ID & Description & Purpose \\
\hline CB05 & Base case run & \multirow{4}{*}{$\begin{array}{l}\text { Relative importance of four different } \\
\text { formation pathways to simulated HONO }\end{array}$} \\
\hline CB05+EM & CB05+HONO emission (R13) & \\
\hline $\mathrm{CB} 05+\mathrm{EM}+\mathrm{HT}$ & $\mathrm{CB} 05+\mathrm{EM}+\mathrm{HONO}$ heterogeneous reaction $((\mathrm{R} 6),(\mathrm{R} 8))$ & \\
\hline $\mathrm{CB} 05+\mathrm{EM}+\mathrm{HT}+\mathrm{SP}$ & $\mathrm{CB} 05+\mathrm{EM}+\mathrm{HT}+\mathrm{HONO}$ surface photolysis $((\mathrm{R} 11),(\mathrm{R} 12))$ & \\
\hline HONO_S/V & $\begin{array}{l}\mathrm{CB} 05+\mathrm{EM}+\mathrm{HT}+\mathrm{SP} \text { with } s_{\max }=1 \text { in building surface area } \\
\text { estimation and soil surface } 0.2\end{array}$ & \multirow{3}{*}{$\begin{array}{l}\text { Sensitivity study of the uncertainties for } \\
\text { selected parameters in HONO formation } \\
\text { mechanism }\end{array}$} \\
\hline HONO_NOx & $\begin{array}{l}\mathrm{CB} 05+\mathrm{EM}+\mathrm{HT}+\mathrm{SP} \text { with } \mathrm{NO}_{x} \text { emission partition } \mathrm{NO} / \mathrm{NO}_{2} / \\
\mathrm{HONO} 85 \% / 13.8 \% / 1.2 \%\end{array}$ & \\
\hline HONO_DV & $\begin{array}{l}\mathrm{CB} 05+\mathrm{EM}+\mathrm{HT}+\mathrm{SP} \text { with deposition velocity of } \mathrm{HONO} \text { has } \\
\text { taken the value as } \mathrm{NO}_{2}\end{array}$ & \\
\hline HONO_G & $\begin{array}{l}\mathrm{CB} 05+\mathrm{EM}+\mathrm{SP}+\mathrm{HONO} \text { heterogeneous reaction on aerosol } \\
\text { and ground surfaces follow Aumont et al. [17] }\end{array}$ & \multirow{2}{*}{$\begin{array}{l}\text { Examine the impacts of other HONO } \\
\text { parameterizations published in peer-reviewed } \\
\text { articles }\end{array}$} \\
\hline HONO_SOA & $\begin{array}{l}\text { CB05+HONO heterogeneous reaction with semivolatile or- } \\
\text { ganic follows Li et al. [18] }\end{array}$ & \\
\hline $0.75 \mathrm{VOC}$ & CB05 with the 25\% VOC emission reduction over PRD region & \multirow{2}{*}{$\begin{array}{l}\text { Evaluation the possible effect on ozone control } \\
\text { strategy due to consideration of additional } \\
\text { HONO formation pathway }\end{array}$} \\
\hline $0.75 \mathrm{VOC} w / \mathrm{HONO}$ & $\begin{array}{l}\mathrm{CB} 05+\mathrm{EM}+\mathrm{HT}+\mathrm{SP} \text { with the } 25 \% \text { VOC emission reduction } \\
\text { over PRD region }\end{array}$ & \\
\hline
\end{tabular}

to the measurements obtained from the Hong Kong Environmental Protection Department (HKEPD) for Yuen Long (YL) monitoring station (Figure 3). Model performance statistics for other locations (CW, TM, TW, TC, and YL) (see Figure 1) are summarized in Table 2. Generally, CMAQ model has skill to reproduce air pollutant mixing ratios, their trends, spatial gradient, and relative abundance. Relatively high indexes of agreement (IOA, [73]) were obtained for all species except aerosol nitrate $\left(\mathrm{ANO}_{3}\right)$. Mean normalized bias $(\mathrm{MNB})$ for $\mathrm{SO}_{2}, \mathrm{NO}_{x}, \mathrm{O}_{3}$, and aerosol sulfate $\left(\mathrm{ASO}_{4}\right)$ are less than $\pm 30 \%$, which is taken as the acceptable level for model performance [74].

Predicted $\mathrm{O}_{3}$ mixing ratios agree reasonably well with observed data in terms of diurnal variation however, it sometimes cannot reproduce high observed afternoon $\mathrm{O}_{3}$ peaks due to the uncertainty of emission precursor $\left(\mathrm{NO}_{x}\right.$ and VOC) ratio estimation and UV calculation for photochemical reaction (Figure 3). Model tends to underestimate $\mathrm{PM}_{2.5}$ mass mixing ratios uniformly by $40 \sim 50 \%$. This may be due to the underestimation of related PM emission rates and missrepresentation of particulate species in the model. Current CMAQ aerosol module [58] allocates all unspecified aerosol components into the category "PM_OTHER" and represents them as chemical inert. The modeled PM2.5 component has a large portion (25\% 40\%) of "PM_OTHER," which may cause the underestimation of specific aerosol component. Modeling results are consistent with the work reported by Kwok et al. [64].

However, the CMAQ model has certain skill to represent sulfate formation pathways via gaseous-phase and aqueousphase chemical reactions. The second pathway is especially important over PRD region due to high ambient $\mathrm{RH}$ and large fraction of cloud cover generally present throughout the year [75]. Simulated $\mathrm{ASO}_{4}$ is reasonably good with IOA around 0.6 and MNB less than $\pm 25 \%$. The grossly underestimation of aerosol nitrate performance (IOA below 0.3 and
MNB greater than $-80 \%$ ) may be due to the underestimation of nitrogen oxide emissions over PRD region and the lack of coarse-mode $\mathrm{ANO}_{3}$ formation in CMAQ 4.6 either through reaction between $\mathrm{HNO}_{3}$ and calcium carbonate or between gaseous $\mathrm{HNO}_{3}$ and $\mathrm{NaCl}$ [64]. Ambient observed $\mathrm{O}_{3}$ and $\mathrm{PM}_{2.5}$ outside Hong Kong are not publicly available; thus, predicted mixing ratios cannot be compared with observed data. In summary, model performance statistics simulation is reasonably well, and the model is suitable for evaluating the impact of HONO chemistry over PRD region.

3.2. Model Evaluation at Xinken (XK) and Guangzhou (GZ). During the PRIDE_PRD2004 campaign, HONO was measured at XK and GZ [49]. XK measurement site is located at a rural area, while GZ measurements site is located at an urban area (Figure 1). The model evaluation after incorporation of different HONO chemistry at XK (first column) and GZ (second column) site for $\mathrm{NO}_{2}, \mathrm{O}_{3}$ and $\mathrm{HONO}$ is presented in Figure 4. Daytime (07:00-18:00 LST) as well as nighttime (19:00-06:00 LST) model average values were compared with corresponding observations. The modeled $\mathrm{NO}_{2}$ mixing ratios for different simulation cases (Table 1) during daytime are underestimated by $26 \% \sim 28 \%$ at XK while during nighttime were overestimated at XK by $21 \% \sim 26 \%$ (no observation for $\mathrm{NO}_{2}$ available at GZ). On the contrary, the modeled $\mathrm{O}_{3}$ mixing ratios are consistently underestimated at two sites, and the degree of underestimation was more severe during daytime ( $-34 \%$ at XK and $-40 \%$ at GZ) than that during nighttime $(-28 \%$ at $\mathrm{XK}$ and $-10 \%$ at GZ). The reason for the underestimation of $\mathrm{O}_{3}$ peaks may be associated with the overestimation of $\mathrm{NO}_{x}$ and missing of $\mathrm{HONO}$ chemistry in base case CMAQ run. However, the HONO chemistry does not have obvious improvement on the $\mathrm{NO}_{2}$ and $\mathrm{O}_{3}$ model performance at XK and GZ sites (pin-pointed with grid area $4.5 \mathrm{~km} \times 4.5 \mathrm{~km}$ ) during the campaign. 


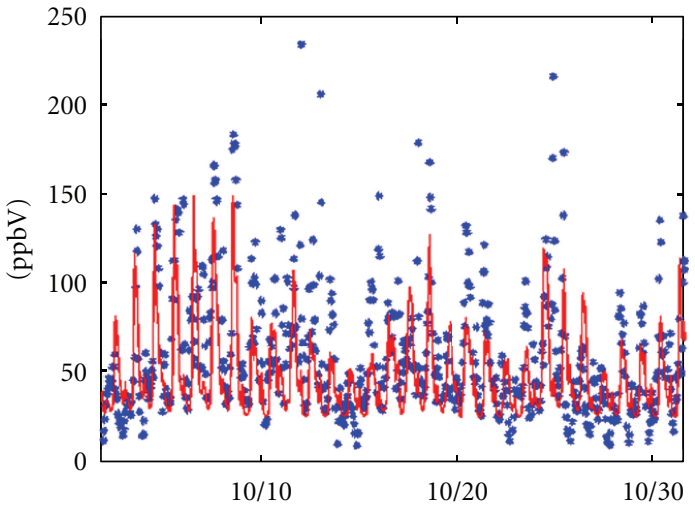

(a) $\mathrm{NO}_{x}$

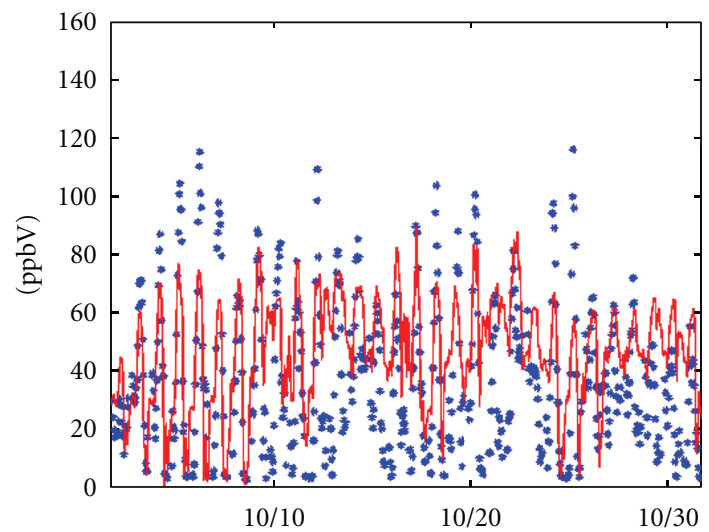

(c) $\mathrm{O}_{3}$

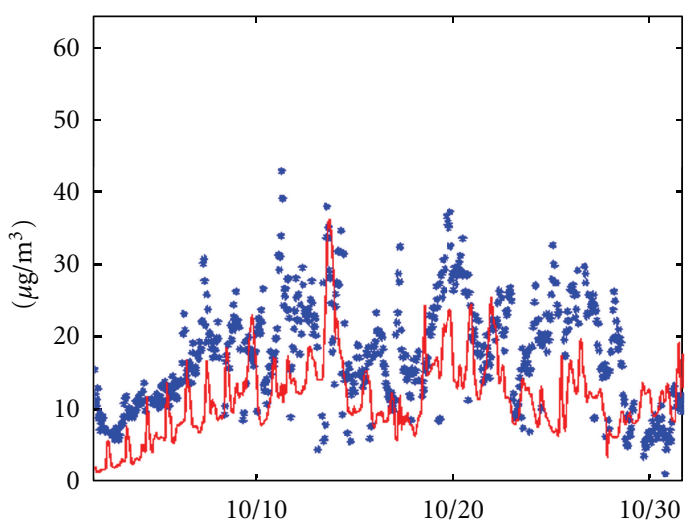

* Obs

Slm

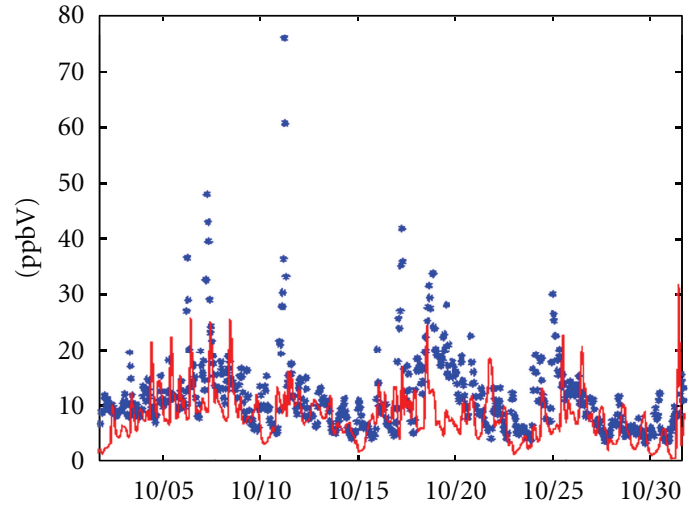

(b) $\mathrm{SO}_{2}$

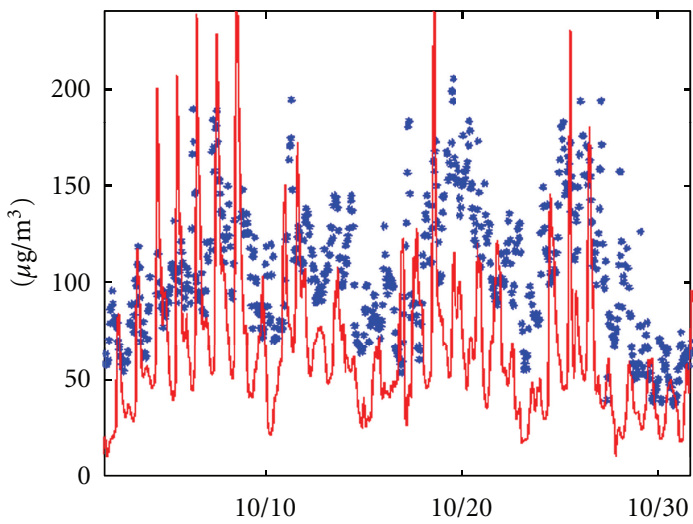

(d) $\mathrm{PM}_{2.5}$

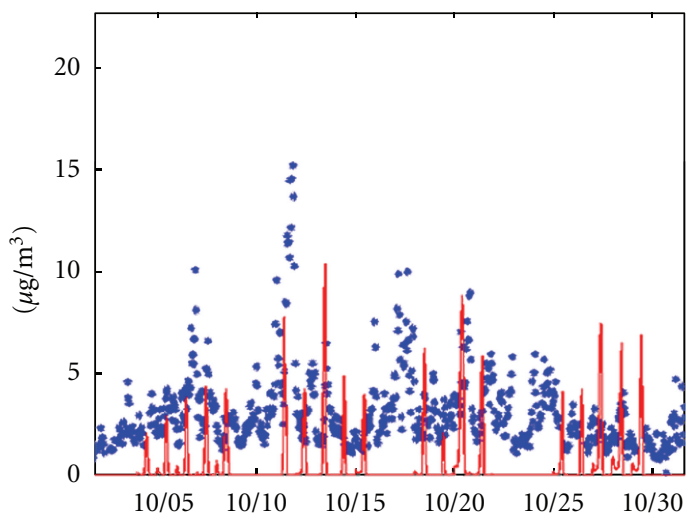

* Obs

- Slm

(e) Sulfate

(f) Nitrate

FIGURE 3: Comparison of modeled and observed (a) $\mathrm{NO}_{x}$, (b) $\mathrm{SO}_{2}$, (c) $\mathrm{O}_{3}$, (d) $\mathrm{PM}_{2.5}$, (e) aerosol sulfate, and (f) aerosol nitrate concentration at Yuen Long (YL) station in October 2004.

However, in other places over PRD region, the HONO chemistry does have potential to enhance the simulated $\mathrm{O}_{3}$ peak value, which will be discussed in Section 3.6.

The modeled HONO mixing ratio increases by an order of magnitude after considering different HONO sources from direct emission, heterogeneous reactions and surface photolysis reactions. The simulation case $\mathrm{CB} 05+\mathrm{EM}+\mathrm{HT}+\mathrm{SP}$ can predict $40 \%$ and $36 \%$ of the observation values in $\mathrm{XK}(1.1 \mathrm{ppbV})$ and $\mathrm{GZ}(4.2 \mathrm{ppbV})$ site, while the values for base case CB05 are only $4 \%$ and $2 \%$, respectively. Normalized mean bias (NMB) at XK is lower during nighttime $(\mathrm{NMB}=-48 \%)$ than that during daytime 
TABLE 2: Model performance of gaseous pollutant and particulate matter simulation over Hong Kong in October 2004 for case CB05.

\begin{tabular}{|c|c|c|c|c|c|c|c|}
\hline & & $\mathrm{SO}_{2}(\mathrm{ppb})$ & $\mathrm{NO}_{x}(\mathrm{ppb})$ & $\mathrm{O}_{3}(\mathrm{ppb})$ & $\mathrm{PM}_{2.5}\left(\mu \mathrm{g} \mathrm{m}^{-3}\right)$ & $\mathrm{ASO}_{4}\left(\mu \mathrm{g} \mathrm{m}^{-3}\right)$ & $\mathrm{ANO}_{3}\left(\mu \mathrm{g} \mathrm{m}^{-3}\right)$ \\
\hline \multirow{6}{*}{ CW } & Obv & 18.6 & 47.3 & 42.5 & 76.2 & 21.6 & 4.4 \\
\hline & Sim & 14.9 & 50.6 & 36.4 & 40.7 & 17.3 & 0.2 \\
\hline & $\mathrm{IOA}^{*}$ & 0.54 & 0.68 & 0.73 & 0.48 & 0.54 & 0.30 \\
\hline & RMSE* & 4.8 & 20 & 14.3 & 41.3 & 12.1 & 4.0 \\
\hline & MNB* (\%) & -19.3 & 7.3 & -23.6 & -44.6 & -16.9 & -95.2 \\
\hline & MNE* (\%) & 39.3 & 48.6 & 42.5 & 45.5 & 38.9 & 95.4 \\
\hline \multirow{6}{*}{$\mathrm{TM}$} & Obv & 8.6 & 18.6 & 63.2 & 62.5 & - & - \\
\hline & Sim & 5.0 & 9.2 & 59.3 & 38.8 & - & - \\
\hline & IOA* & 0.44 & 0.44 & 0.75 & 0.51 & - & - \\
\hline & RMSE* & 3.6 & 11 & 11.1 & 33.6 & - & - \\
\hline & MNB* (\%) & -26.9 & -50.2 & -3.9 & -39.8 & - & - \\
\hline & MNE* (\%) & 52.1 & 57.3 & 25.1 & 48.2 & - & - \\
\hline \multirow{6}{*}{ TW } & Obv & 11.0 & 70.6 & 53.7 & 69.3 & - & - \\
\hline & Sim & 6.8 & 62.8 & 30.2 & 35.5 & - & - \\
\hline & $\mathrm{IOA}^{*}$ & 0.43 & 0.59 & 0.52 & 0.50 & - & - \\
\hline & RMSE* & 4.5 & 39 & 21.6 & 40.9 & - & - \\
\hline & MNB* (\%) & -40.3 & -10.6 & -47.6 & -40.5 & - & - \\
\hline & MNE* (\%) & 48.3 & 55.2 & 79.6 & 44.6 & - & - \\
\hline \multirow{6}{*}{ TC } & Obv & 16.9 & 43.2 & 80.6 & 72.6 & - & - \\
\hline & Sim & 11.2 & 36.1 & 59.1 & 44.9 & - & - \\
\hline & IOA & 0.58 & 0.71 & 0.77 & 0.43 & - & - \\
\hline & RMSE & 6.9 & 21 & 18.2 & 45.1 & - & - \\
\hline & MNB (\%) & -26.3 & -10.8 & -33.2 & -40.6 & - & - \\
\hline & MNE (\%) & 50.3 & 47.2 & 54.3 & 42.5 & - & - \\
\hline \multirow{6}{*}{ YL } & Obv & 24.9 & 84.1 & 89.3 & 72.6 & 18.3 & 6.9 \\
\hline & Sim & 18.6 & 47.6 & 60.2 & 45.1 & 14.3 & 1.3 \\
\hline & $\mathrm{IOA}^{*}$ & 0.49 & 0.65 & 0.81 & 0.56 & 0.56 & 0.29 \\
\hline & RMSE* & 5.2 & 36 & 15.3 & 40.2 & 10.3 & 6.1 \\
\hline & MNB* (\%) & -22.1 & -40.1 & -28.1 & -45.1 & -23.5 & -81.7 \\
\hline & MNE* (\%) & 44.1 & 54.1 & 39.9 & 49.6 & 39.6 & 83.7 \\
\hline
\end{tabular}

* IOA: index of agreement, RMSE: root mean square error, MNB: mean normalized bias, MNE: mean normalized error.

$(\mathrm{NMB}=-71 \%)$, while at $\mathrm{GZ}$ site, the result is opposite $(\mathrm{NMB}=-63 \%$ during nighttime and $(\mathrm{NMB}=-57 \%$ during daytime). Verification for hourly HONO observations at $\mathrm{XK}$ site [52] shows that case $\mathrm{CB} 05+\mathrm{EM}+\mathrm{HT}+\mathrm{SP}$ can improve the model performance with the statistic metrics NMB from $-95 \%$ to $-54 \%$ and IOA from 0.35 to 0.56 compared with case CB05.

Predicted daytime average $\mathrm{OH}$ was $2.2 \times 10^{6} \mathrm{molec} \cdot \mathrm{cm}^{-3}$ at $\mathrm{XK}$ for case $\mathrm{CB} 05$ (homogeneous reactions only) which increased to $2.3 \times 10^{6} \mathrm{molec} \cdot \mathrm{cm}^{-3}, 2.4 \times 10^{6} \mathrm{molec} \cdot \mathrm{cm}^{-3}$, $2.5 \times 10^{6} \mathrm{molec} \cdot \mathrm{cm}^{-3}$ for case $\mathrm{CB} 05+\mathrm{EM}, \mathrm{CB} 05+\mathrm{EM}+\mathrm{HT}$, and case $\mathrm{CB} 05+\mathrm{EM}+\mathrm{HT}+\mathrm{SP}$, respectively. Predicted daytime average $\mathrm{OH}$ was $1.5 \times 10^{6} \mathrm{molec} \cdot \mathrm{cm}^{-3}$ at $\mathrm{GZ}$ for case CB05 (homogeneous reactions only) which increased to $1.7 \times 10^{6} \mathrm{molec} \cdot \mathrm{cm}^{-3}, 1.8 \times 10^{6} \mathrm{molec} \cdot \mathrm{cm}^{-3}, 1.9 \times$ $10^{6} \mathrm{molec} \cdot \mathrm{cm}^{-3}$ for case $\mathrm{CB} 05+\mathrm{EM}, \mathrm{CB} 05+\mathrm{EM}+\mathrm{HT}$, and $\mathrm{CB} 05+\mathrm{EM}+\mathrm{HT}+\mathrm{SP}$, respectively. Thus, the additional HONO sources increased daytime $\mathrm{OH}$ by $13.6 \%$ and $26.7 \%$ at XK and GZ, respectively. OH concentration was measured during PRD-PRIDE 2006 campaign at the upper wind of
Guangzhou city [51]; the typical average daytime $\mathrm{OH}$ concentration in the similar is above $5 \times 10^{6} \mathrm{molec} \cdot \mathrm{cm}^{-3}$, which is a factor of two higher than the simulated $\mathrm{OH}$ value here in GZ. It may suggest that current MM5-CMAQ modeling system tends to underestimate overall oxidization capacity due to the large uncertainty in VOC emission estimation over PRD region [76].

3.3. Spatial Pattern of HONO Simulation. Spatial patterns of simulated HONO distributions during daytime (Figures $5(\mathrm{a})-5(\mathrm{~d})$ ) and nighttime (Figures $5(\mathrm{e})-5(\mathrm{~h})$ ) are presented in Figure 5 separately. The HONO fields for different cases in Figure 5 are the daily average of October 28 with the maximum ozone enhancement during the simulation period. The distribution patterns of simulated HONO for daytime and nighttime are generally consistent with the $\mathrm{NO}_{x}$ emission pattern, which is due to the fact that HONO formation pathways are related to $\mathrm{NO}_{2}$. Remarkable contrast for predicted daytime and nighttime $\mathrm{HONO}$ mixing ratio exists in different simulation cases. Mean nighttime HONO 

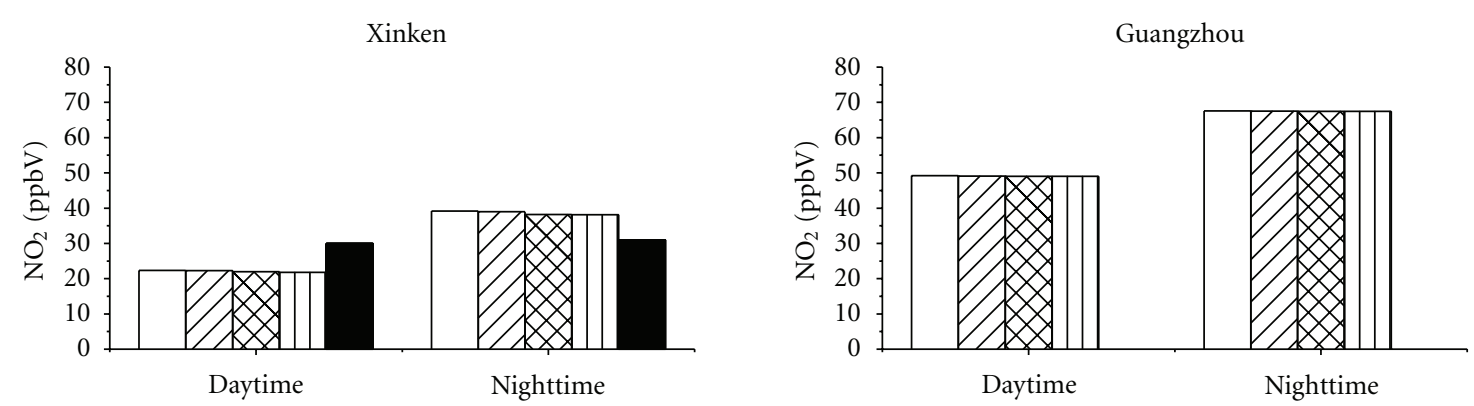

(a)
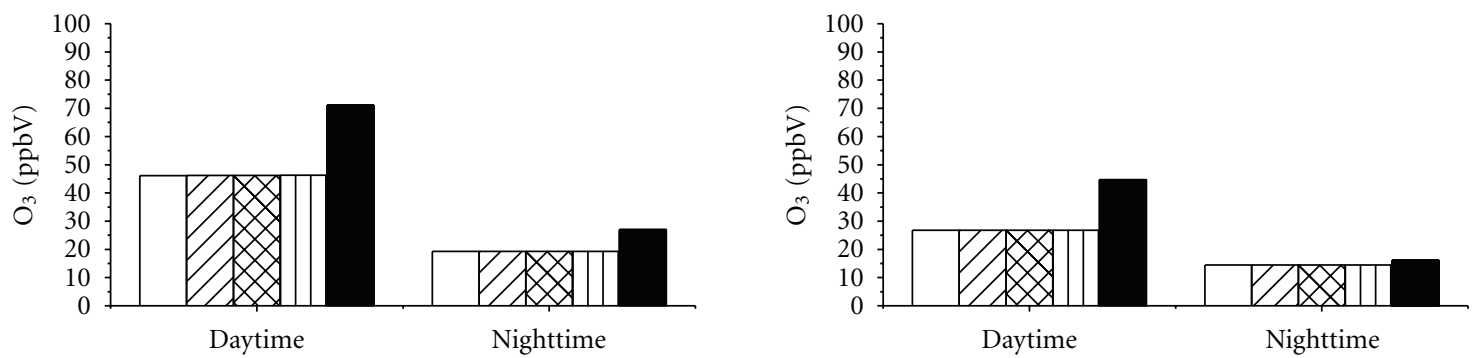

(b)
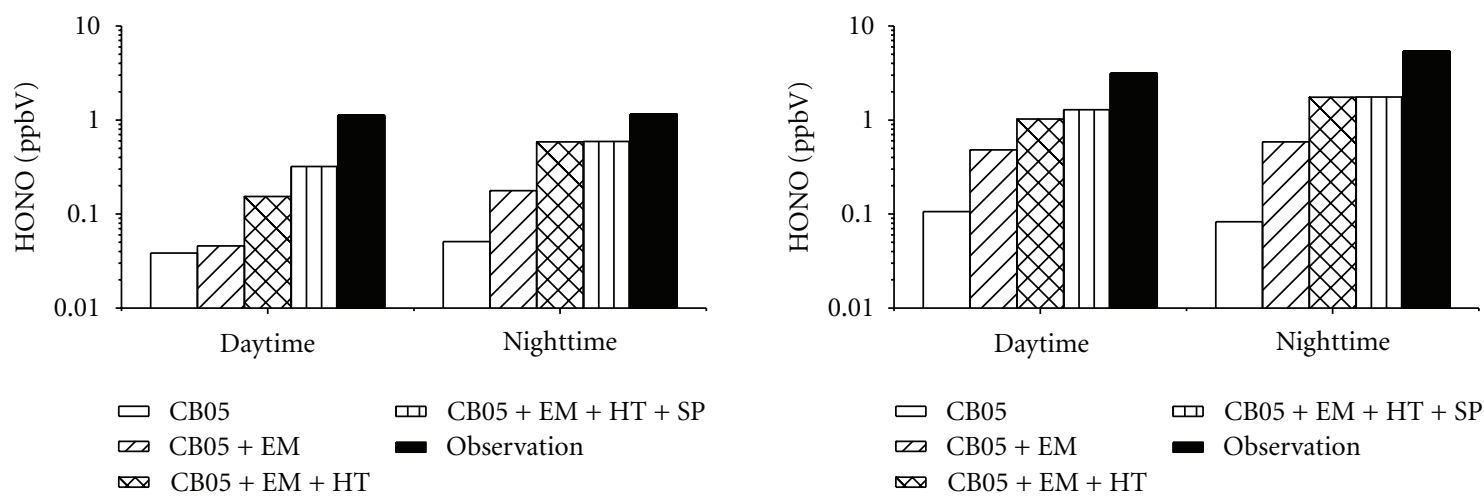

(c)

Figure 4: Model validations after incorporation of different HONO chemistry at Xinken (XK) and Guangzhou (GZ) site for (a) NO ${ }_{2}$, (b) $\mathrm{O}_{3}$, and (c) HONO simulation.

mixing ratio is about twice that of daytime value. For case $\mathrm{CB} 05+\mathrm{EM}+\mathrm{HT}$, this night-to-day contrast is more pronounced. Over the GZ area, the mean daytime HONO mixing ratio is around $2 \mathrm{ppbV}$ while the predicted nighttime value is above $5 \mathrm{ppbV}$.

The simulated HONO level from base case (case CB05) is low with the mean daytime value of less than $500 \mathrm{pptV}$ and nighttime value of $800 \mathrm{pptV}$. The addition of HONO emission (case $\mathrm{CB} 05+\mathrm{EM}$ ) increased predicted $\mathrm{HONO}$ by $2 \sim 3$ times. The heterogeneous reactions (case $\mathrm{CB} 05+\mathrm{EM}+\mathrm{HT}$ ) and surface photolysis (case $\mathrm{CB} 05+\mathrm{EM}+\mathrm{HT}+\mathrm{SP}$ ) further enhanced the modeled HONO level, which resulted in more than $8 \sim 10$ times greater than homogenous reaction only. Surface photolysis contributes more to the HONO enhancement during daytime due to the available solar radiation (the difference between Figures 5(c) and 5(d)), whereas heterogeneous reactions play a more important role in $\mathrm{HONO}$ formation at nighttime (the difference between Figures 5(g) and 5(f) is as large as 200\%). Results are consistent with those reported by Sarwar et al. [46].

\subsection{Relative Contribution to HONO from Different Forma-} tion Pathways. The average diurnal relative contribution of the four HONO sources to predicted HONO concentration in $\mathrm{XK}$ and GZ site is shown in Figure 6. The relative contribution at each site is counted by subtracting the mean predicted value of different formation pathways (emission, heterogeneous reaction, and photolysis) to corresponding base case one at each hour. It can be found that the predicted nighttime HONO concentration is primarily controlled by heterogeneous reaction both at rural and urban sites (up to $89 \%$ in $\mathrm{XK}$ and $81 \%$ in GZ). During daytime, the contribution of surface photolysis increases with the increase of solar radiation. The maximum contribution can reach up to $64 \%$ in $\mathrm{XK}$ and $31 \%$ in GZ at the late afternoon. The relative contribution of direct $\mathrm{HONO}$ emission in rural 


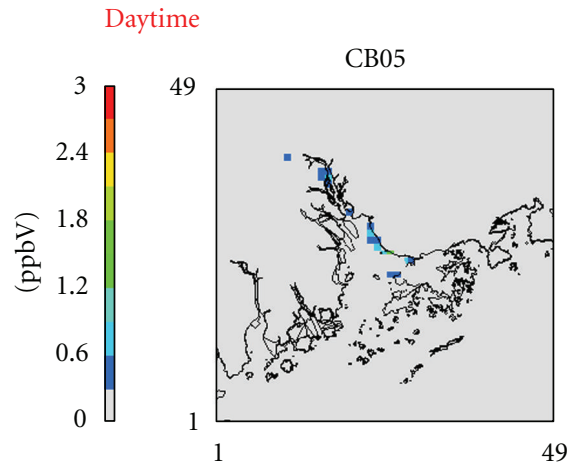

(a)

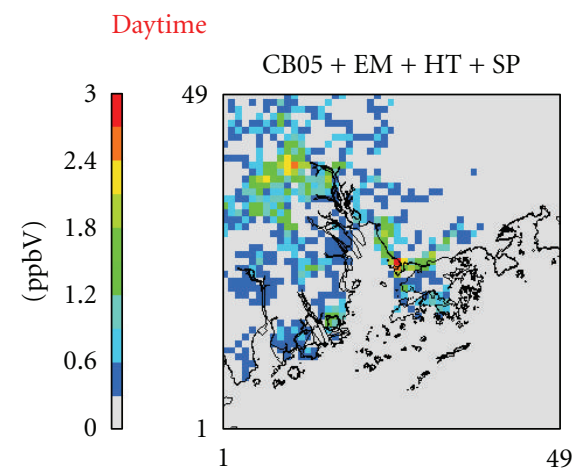

(d)
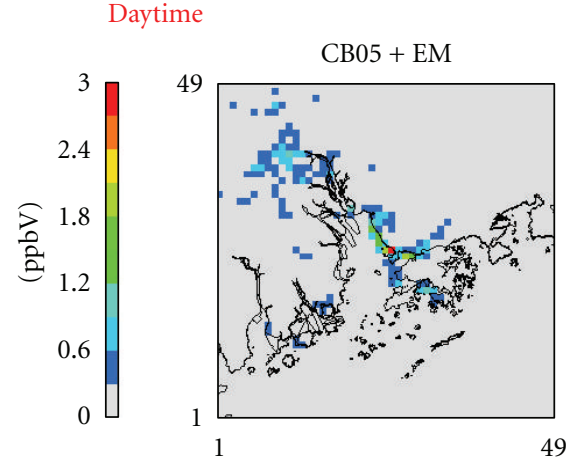

(b)

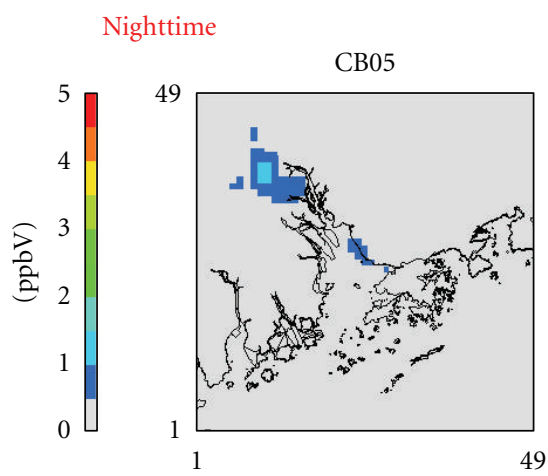

(e)

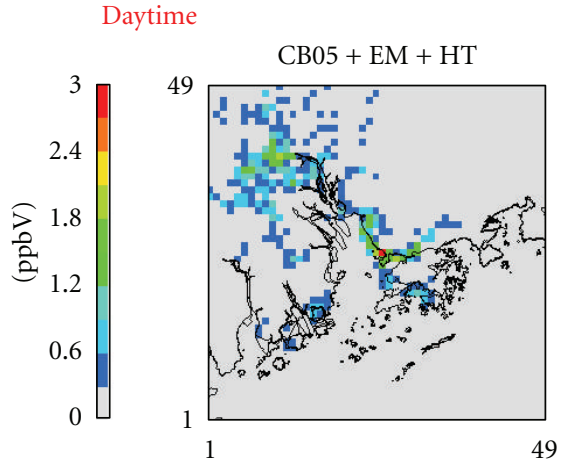

(c)

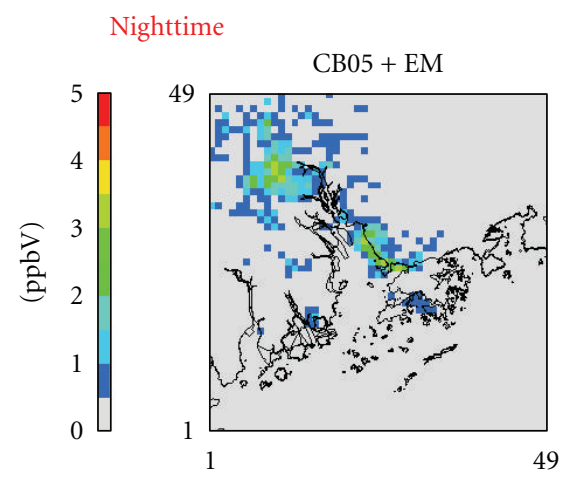

(f)

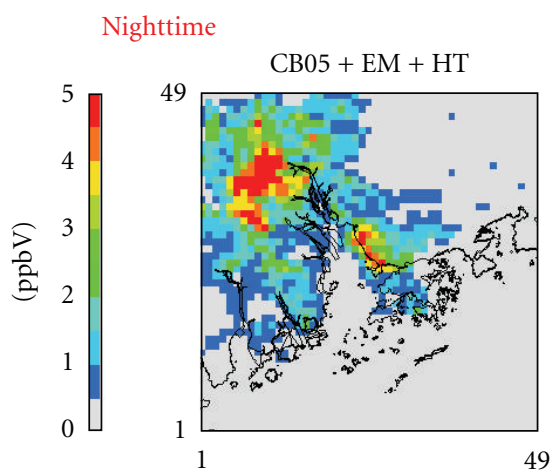

(g)

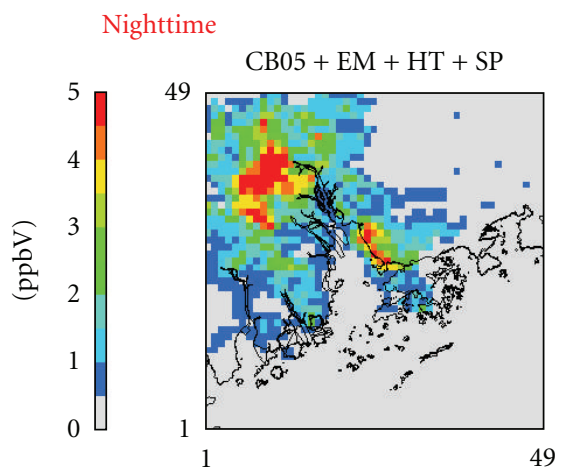

(h)

FIGURE 5: Spatial distribution of simulated HONO through homogeneous reactions, direct emission, heterogeneous reaction, and surface photolysis formation pathway at daytime $(\mathrm{a}-\mathrm{d})$ and nighttime $(\mathrm{e}-\mathrm{h})$.

site is greater at night and nearly negligible during the day due to very low traffic volume. The relative contribution of direct HONO emissions at urban site is relatively high (20$30 \%$ ) with peak observed during morning and evening rush hour. The relatively high contribution from direct emission at GZ suggests the importance of accurately speciating $\mathrm{NO}_{x}$ emission from vehicles (e.g., reaction (R13)).

\subsection{Sensitivity Study of Different HONO Simulation Cases.} Three additional model simulations were conducted to investigate the sensitivity of different parameters on simulated HONO. The first parameter investigated is the $\mathrm{NO}_{x}$ emission (from motor vehicle) speciation. For air quality modeling studies, $\mathrm{NO}_{x}$ emissions are typically speciated into $\mathrm{NO}$ and $\mathrm{NO}_{2}$ by $90 \%$ and $10 \%$, respectively (by volume). Long-term observation of $\mathrm{NO}_{2} / \mathrm{NO}$ ratio in Hong Kong from vehicle emission suggested that the traditional speciation for $\mathrm{NO}_{x}$ emission may not be suitable for PRD area [77]. Higher $\mathrm{NO}_{2}$ emission contribution may be due to the unique condition of mobile fleet composition and engine type usage in Hong Kong. Hence, a sensitivity run (case $\mathrm{HONO} \_\mathrm{NO}_{x}$ ) by using alternative $\mathrm{NO}_{x}$ emissions speciation is designed. For this study, $\mathrm{NO}_{x}$ was speciated into $\mathrm{NO}, \mathrm{NO}_{2}$, and $\mathrm{HONO}$ by $85 \%, 13.8 \%$, and $1.2 \%$. In this sensitivity run, the impact of increased direct HONO emission on predicted HONO is investigated. The second parameter for the sensitivity 


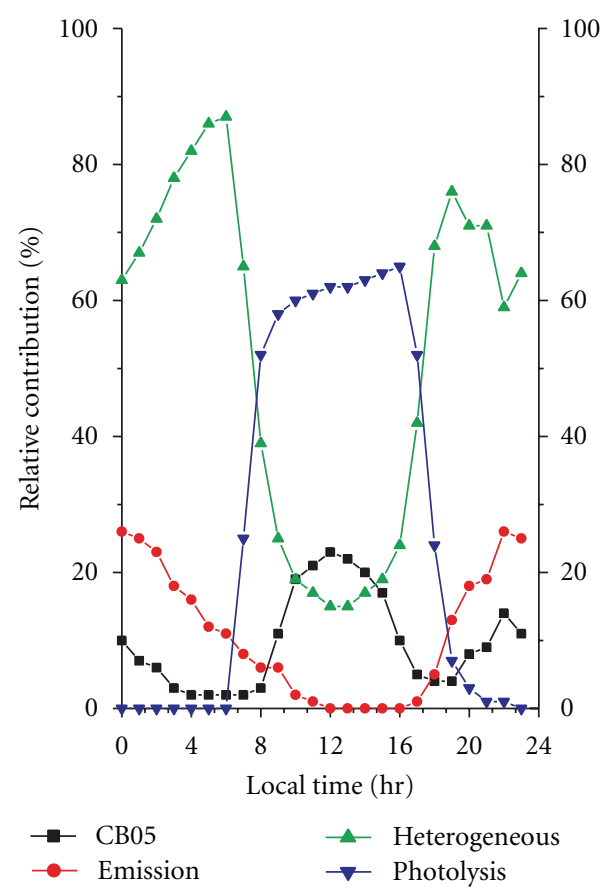

(a)

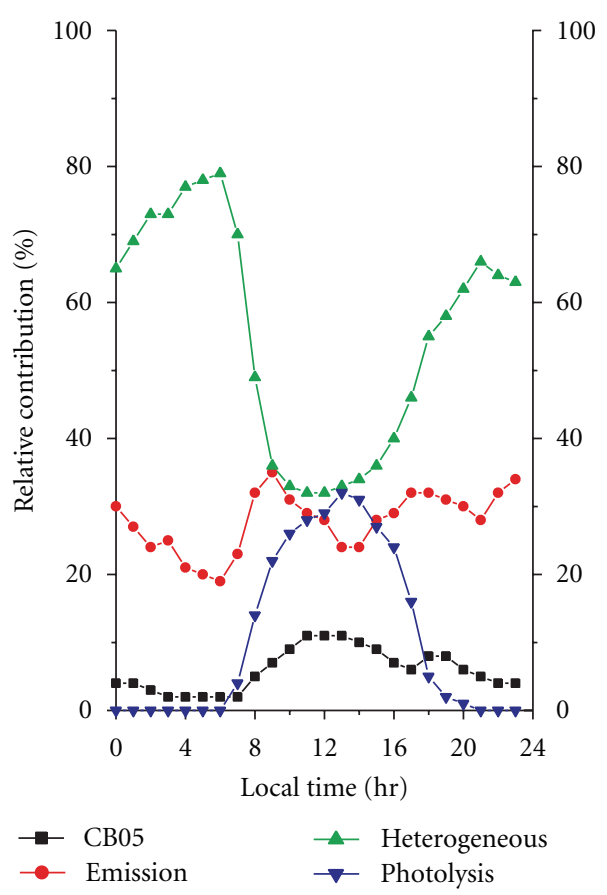

(b)

Figure 6: Average relative contributions of different HONO sources to predicted ground HONO concentration at (a) Xinken and (b) Guangzhou.

runs is the available surface area for heterogeneous reaction (case $\mathrm{HONO}_{-} / \mathrm{V}$ ). In case of $\mathrm{CB} 05+\mathrm{EM}+\mathrm{HT}+\mathrm{SP}$, [S/V] ratio for soil surface was set at $0.1 \mathrm{~m}^{-1}$, and the $[S / V]$ for building surface in (3) was estimated using an $s_{\max }=$ $0.3 \mathrm{~m}^{-1}$. For PRD region, especially along the PRE area, the urban density and average building height are much higher than that in US condition [78] and hence may provide more available interface for heterogeneous reaction. For this study, $s_{\max }=1.0 \mathrm{~m}^{-1}$ and $[S / V]_{\text {soil }}=0.2 \mathrm{~m}^{-1}$ were used. The third parameter is the HONO deposition velocity (case HONO_DV). An alternative lower deposition velocity taken the value of $\mathrm{NO}_{2}$ was used as the surrogate in the model to increase the chance for surface HONO accumulation.

Figure 7 gives the diurnal pattern of simulated $\mathrm{HONO}$ at XK and GZ with different simulation cases. The mean observation diurnal variation with error bars over PRIDEPRD2004 campaign is from Figure 3 of Zhang et al. [49]. The diurnal variation of different simulation cases is the mean of each local hour HONO mixing ratio over the simulation window. The characteristic of HONO diurnal profile over $\mathrm{PRD}$ region with high peak at night and relatively low during morning is consistent with the observation worldwide $[9,11-13]$. The adding of direct emission (case CB05+EM) contributed to the HONO morning peak at the rush hour 0700 0800 local standard time (LST). The adding of heterogeneous reaction (case $\mathrm{CB} 05+\mathrm{EM}+\mathrm{HT}$ ) mainly contributed to the late afternoon (17:00-22:00 LST) buildup of HONO concentration. The simulation case HONO_S/V nearly followed the observed HONO diurnal variation pattern at GZ, but in XK, it shows that the large overestimation occurred after sunset. However, the current implementation cannot repeat observed elevated HONO level late at night (02:00 06:00 LST); the model tends to have the steep jump after the peak near the midnight.

Simulated daytime and nighttime mean HONO mixing ratios at $\mathrm{XK}$ and GZ for different simulation cases are presented in Figure 8. Mean observed HONO at GZ at daytime is $4.17 \mathrm{ppbV}$, which is nearly four times greater than that at XK (1.12 ppbV). GZ site is located at an urban area, and $\mathrm{NO}_{2}$ mixing ratios are much greater than those at the rural XK site. Thus, observed $\mathrm{HONO}$ at GZ is much greater than that at XK. Homogenous reactions (case CB05) can only explain $5 \%$ or less of the observed HONO, whereas the heterogeneous reactions contribute more than $30 \%$ of observed value both in daytime and nighttime.

Compared with simulation case $\mathrm{CB} 05+\mathrm{EM}+\mathrm{HT}+\mathrm{SP}$, HONO increases at GZ from sensitivity run HONO_DV, HONO_NO ${ }_{x}$, and HONO_S/V are $17 \%, 13 \%$, and $157 \%$, respectively; while at XK, the values are $37 \%, 9 \%$, and $207 \%$. The improvement at nighttime is better than that in daytime. Predicted HONO for HONO_S/ $V$ case agrees well both at GZ and XK at daytime but overestimates $60 \%$ during nighttime at XK. Results of sensitivity runs may suggest the importance of $[S / V]$ value for simulating HONO chemistry. While the PRD region has relatively high urban density and greater building height, the $s_{\max }$ value is not currently known. The model with $s_{\max }=1$ predicts HONO levels closer to the observed data in PRD both in terms of mean and diurnal variation. The details of the HONO chemistry are still unknown. The use of currently known HONO reactions in air quality model does not reproduce observed HONO levels in PRD. Until the details of the HONO chemistry are known, 


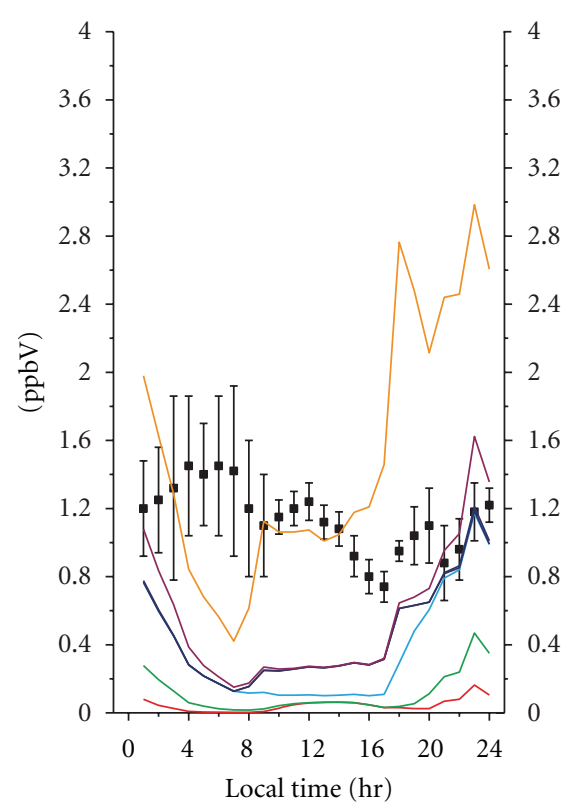

$\begin{array}{ll}- \text { Observation } & - \text { CB05 + EM + HT + SP } \\ \text { CB05 } & \text { HONO_S/V } \\ \text { CB05 + EM } & - \text { HONO_NOX } \\ \text { CB05 }+ \text { EM + HT }- \text { HONO_DV }\end{array}$

(a)

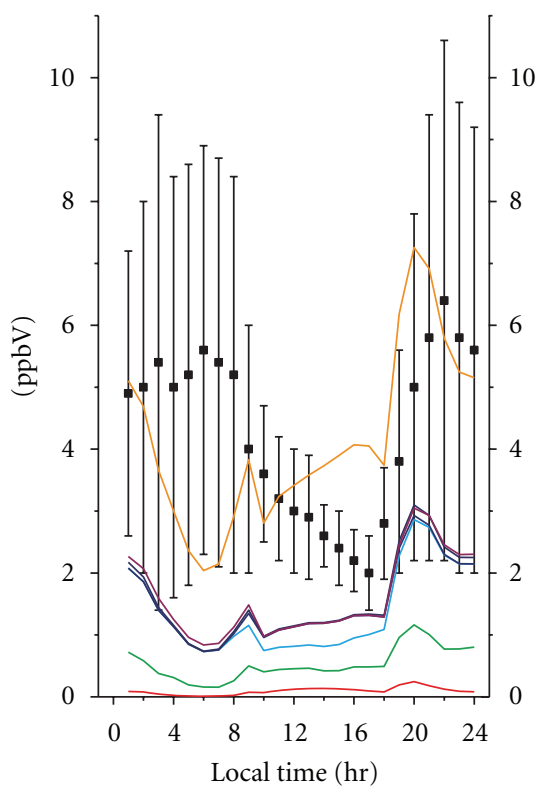

$\begin{array}{ll}-\begin{array}{ll}\text { Observation } \\ \text { CB05 }\end{array} & \text { CB05 + EM + HT + SP } \\ \text { CB05 + EM } & \text { HONO_S/V } \\ \text { CB05 + EM + HT }- \text { HONO_NOX } \\ \text { HONO_DV }\end{array}$

(b)

Figure 7: Diurnal pattern of simulated HONO at (a) Xinken and (b) Guangzhou with difference simulation cases.

this $s_{\max }$ value can be used in the model for PRD. This is an empirical parameter that produces HONO closer to observed data in PRD and is not intended for other urban areas.

The production of HONO via heterogeneous reaction at ground using procedure described by Aumont et al. [17] (case HONO_G) was also tested. Consistent with the results reported, Sarwar et al. [46] predicted nighttime HONO was $30 \%-67 \%$ lower than the values obtained with $\mathrm{CB} 05+\mathrm{EM}+\mathrm{HT}+\mathrm{SP}$ and $66 \%-236 \%$ lower than the observed data.

The importance of HONO formation from heterogeneous reaction on semivolatile organics was also examined (case HONO_SOA) using the procedure of Li et al. [18]. HONO production from diesel bound $\mathrm{NO}_{x}$ emission at ground was parameterized as HONO source using the conversion factor of 0.023 . The predicted daytime and nighttime mean HONO mixing ratios are $18 \%-33 \%$ higher than that of case $\mathrm{CB} 05+\mathrm{EM}+\mathrm{HT}+\mathrm{SP}$ but with larger variations (see Figure 8). However, the results were still $43 \%-57 \%$ and $19 \%-$ $54 \%$ lower than corresponding observed data at nighttime and daytime, which suggests that the contribution of the semivolatile organics heterogeneous reaction to HONO formation may subject to high uncertainty and need to parameterize carefully in future.

3.6. Impact of HONO Chemistry on Ozone and PM. The spatial distribution of the largest enhancements of daily maximum 8-hour $\mathrm{O}_{3}$ and daily mean $\mathrm{PM}_{2.5}$ due to the additional
HONO sources is presented in Figure 9. The largest enhancement occurred on October 28th with northeasterly moderate synoptic wind and relatively steady atmosphere [72]. Daily maximum 8-hour $\mathrm{O}_{3}$ increased by up to $6 \mathrm{ppbV}$ near the downwind of GZ city with simulated $\mathrm{O}_{3}$ level of $90 \mathrm{ppbV}$ in base case run (case CB05). The impact on daily mean $\mathrm{PM}_{2.5}$ is relatively significant with the largest increase of nearly $17 \mu \mathrm{g} / \mathrm{m}^{3}$ or $12 \%$ at GZ, the downwind of GZ, Shenzhen area, and northwest of Hong Kong. The impact of additional HONO sources on aerosol sulfate and secondary organic aerosols was small; however, the impact on ammonium and nitrate was relatively large $\left(3.6\right.$ and $12.0 \mu \mathrm{g} / \mathrm{m}^{3}$, resp.) which subsequently enhanced $\mathrm{PM}_{2.5}$. The additional $\mathrm{OH}$ from the photolysis of enhanced $\mathrm{HONO}$ reacts with $\mathrm{NO}_{2}$ and produces additional $\mathrm{HNO}_{3}$ which subsequently generates greater aerosol nitrate and ammonium.

The largest enhancement in morning $\mathrm{O}_{3}$ (8 am noon), daily maximum 8 -hour $\mathrm{O}_{3}$, and daily mean $\mathrm{PM}_{2.5}$ in the modeling domain for each day is shown in Table 3 . The largest enhancement in daily maximum 8-hour $\mathrm{O}_{3}$ ranged between 3 and $7 \mathrm{ppbV}$, while the largest enhancement in morning $\mathrm{O}_{3}$ ranged between 3 and 9 ppbV. Levels of the morning $\mathrm{O}_{3}$ increases are generally similar to those of daily maximum 8-hour $\mathrm{O}_{3}$. The accumulated $\mathrm{HONO}$ at night undergoes photolysis during the day and produces $\mathrm{OH}$ which drives the photochemistry and enhances $\mathrm{O}_{3}$. The largest enhancement in daily mean $\mathrm{PM}_{2.5}$ ranged between 4 and $17 \mu \mathrm{g} / \mathrm{m}^{3}$. As mentioned earlier, ambient observed $\mathrm{O}_{3}$ and $\mathrm{PM}_{2.5}$ data in PRD region outside Hong Kong are not 


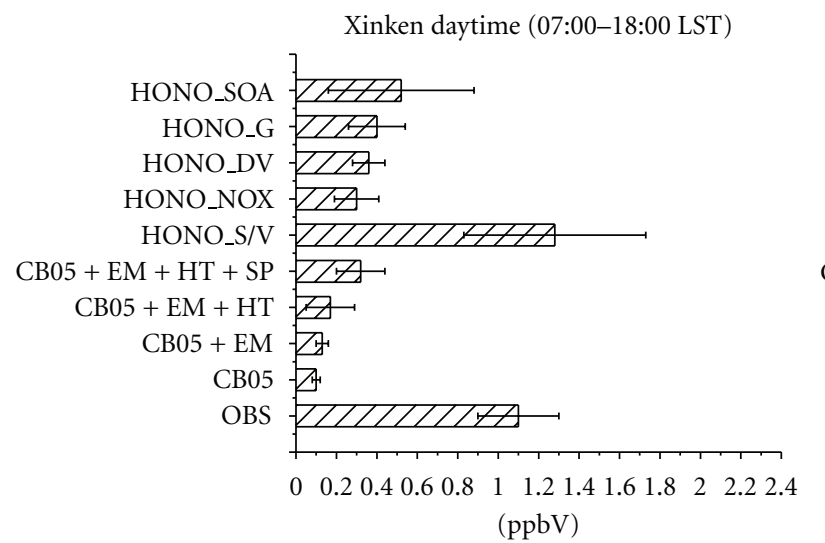

(a)

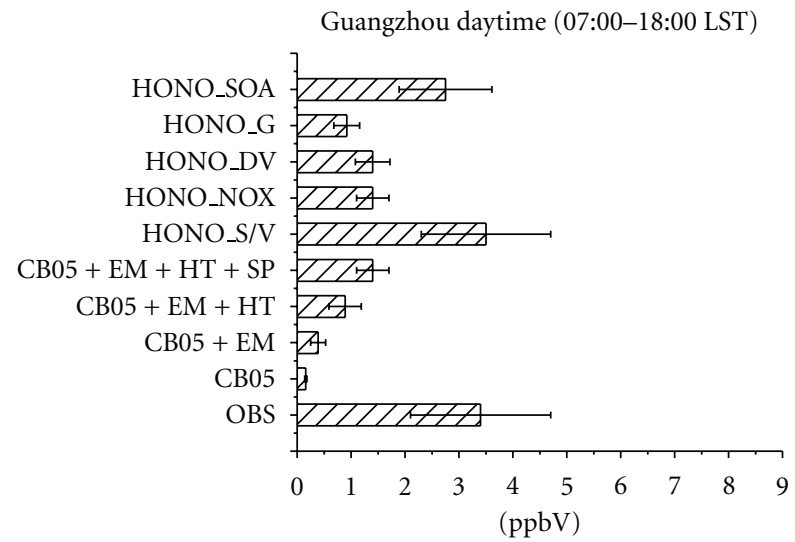

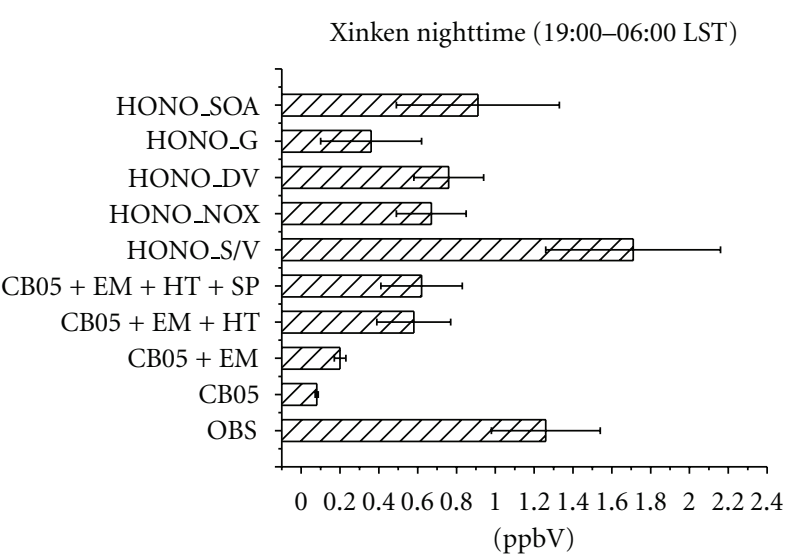

Guangzhou nighttime (19:00-06:00 LST)

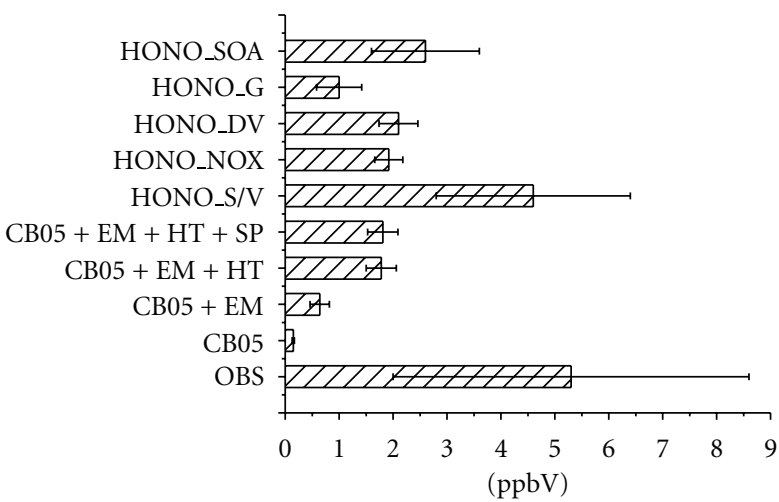

(b)

FIgURE 8: Simulated mean daytime and nighttime HONO concentration in (a) Xinken and (b) Guangzhou for different simulation case.

publicly available, and thus, increases in predicted mixing ratios cannot be compared with observed data.

The impact of additional HONO sources on $\mathrm{O}_{3}$ control strategy is also investigated. Urban areas of PRD are mostly VOC limited for $\mathrm{O}_{3}$ production [49]; thus, only response of $25 \%$ VOC emission reduction was investigated (cases $0.75 \mathrm{VOC}$ and $0.75 \mathrm{VOC} \mathrm{w} / \mathrm{HONO}$ ). The relative response factor (RRF) is calculated to quantify the response of $\mathrm{O}_{3}$ under different chemical mechanisms. RRF is the average ratio of simulated $\mathrm{O}_{3}$ mixing ratio with and without reduced emissions. RRF at several cities over PRD with and without additional HONO sources is presented in Figure 10. Relatively high response was obtained in cities where intensive $\mathrm{NO}_{x}$ and VOC emissions are present. The use of additional sources affected the RRF for many cities as shown in the figure. For example, predicted RRF without the additional HONO sources at FS was $0.87\left(13 \% \mathrm{O}_{3}\right.$ decrease $)$ due to the $25 \%$ VOC emission reduction. The inclusion of additional HONO sources changed the RRF to 0.85 or $15 \% \mathrm{O}_{3}$ decrease due to the same VOC emission reduction (2\% increase in $\mathrm{O}_{3}$ response). Impact on RRF at other cities was also similar. Thus, the use of additional HONO sources in the model affects the $\mathrm{O}_{3}$ control strategy.

\section{Summary}

This study investigated the contribution of HONO sources to the photochemistry over PRD using the MM5-SMOKECMAQ model system. In addition to the gas-phase reactions, additional heterogeneous and surface photolysis $\mathrm{HONO}$ formation pathways and direct emissions were incorporated into the model. 10-day ozone episode in October 2004 was chosen to simulate impact of different HONO sources to $\mathrm{HONO}$ formation and ozone and $\mathrm{PM}_{2.5}$ yields. The inclusion of additional sources improved HONO predictions significantly with HONO enhancement 8-10 times greater than homogenous reaction. The simulated HONO mean diurnal profiles were compared with observations at rural site XK and urban site GZ. The model can generally produce the daytime variation but cannot maintain the observed elevated HONO late at night. In terms of the relative contribution of different pathway to HONO formation, the weighting from homogenous reaction is no more than $10 \%$ both at urban and rural site, while the heterogeneous and daytime surface photolysis reactions can dominate $69 \% \sim 83 \%$ contributions with comparable weightings. Direct emission contribution is more important at urban site than that in rural site. 

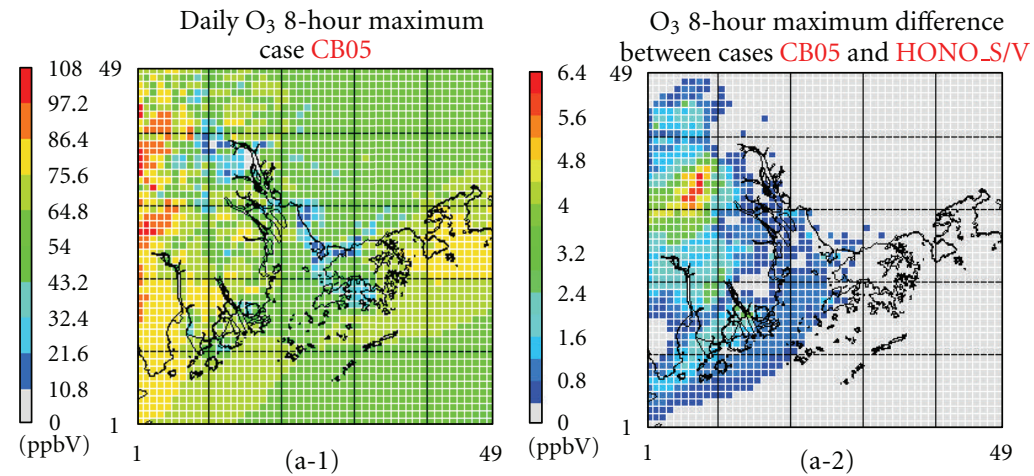

(a)
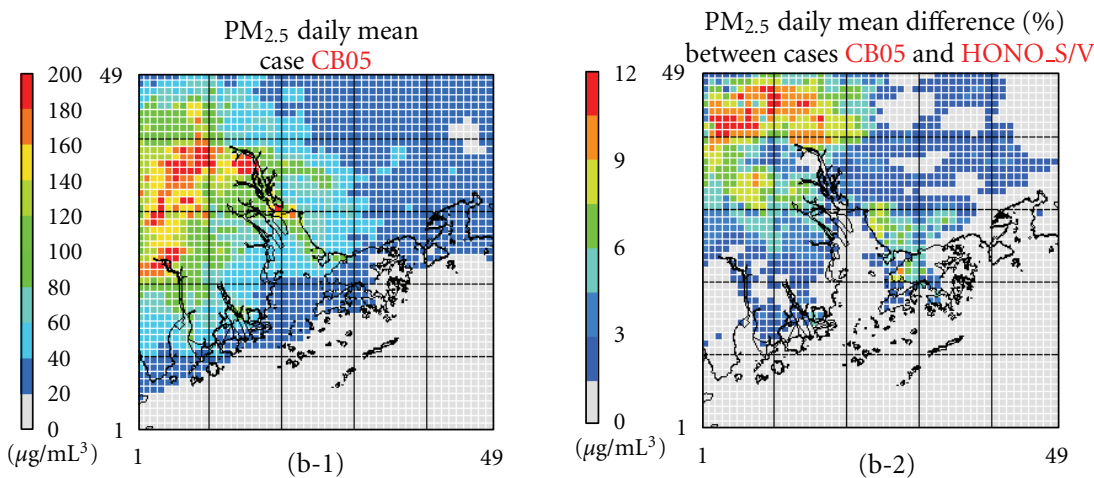

(b)

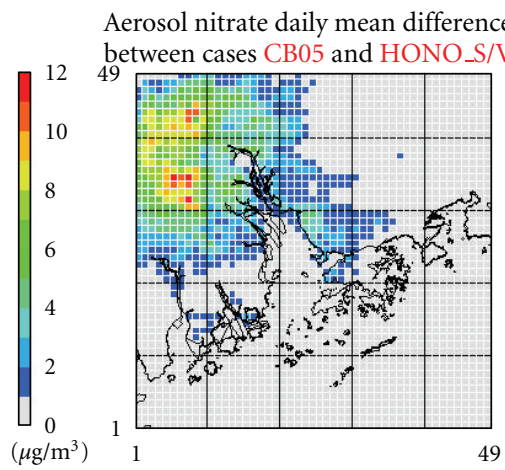

(d)

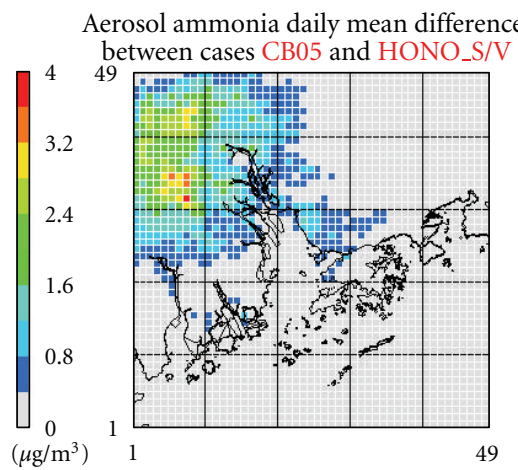

(e)

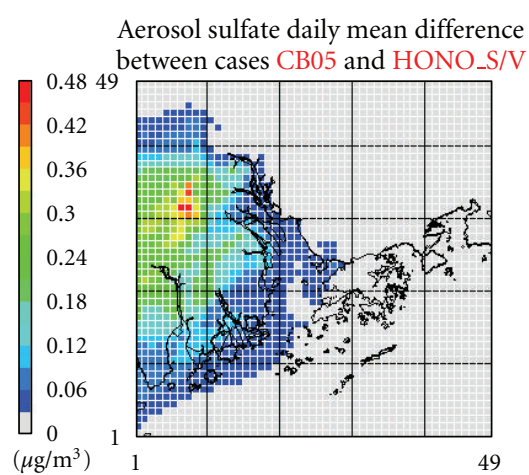

(c)

SOA daily mean difference

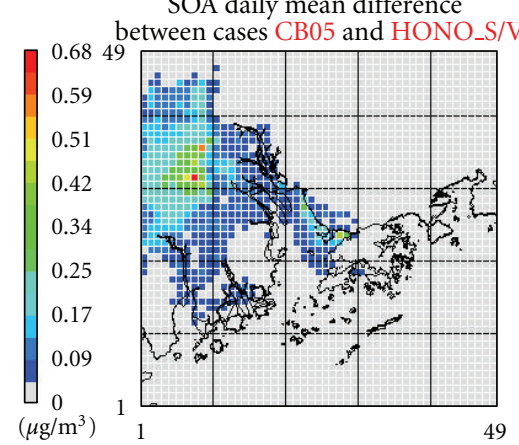

(f)

FIgURE 9: Spatial distribution of the maximum enhancement due to the HONO chemistry during the entire simulation period for (a)* daily 8-hour maximum ozone, (b)* daily mean $\mathrm{PM}_{2.5}$, (c) daily mean aerosol sulfate, (d) daily mean aerosol nitrate, (e) daily mean aerosol ammonia, and (f) daily mean SOA. *(a-1) and (b-1) are the spatial distribution of base case simulation CB05, while (a-2) and (b-2) are the spatial distribution of difference between simulation cases HONO_S/V and CB05 (see Table 1).

The inclusion of additional HONO sources enhanced daily maximum 8-hour $\mathrm{O}_{3}$ by up to $7 \mathrm{ppbV}(8 \%)$ and daily average $\mathrm{PM}_{2.5}$ up to $17 \mu \mathrm{g} / \mathrm{m}^{3}$ (12\%) over the downwind area of GZ. The use of additional HONO sources also affected the $\mathrm{O}_{3}$ control strategy.

Results of sensitivity studies suggest that the parameterization of surface area for heterogeneous reactions is an important factor that can affect simulated HONO. However, surface area estimates needed for these heterogeneous reactions are not currently available; hence, implementations of these reactions in air quality models require simplifying assumptions. Thus, the details of these reactions (e.g., their dependence on types of surface, relative humidity, etc.) along with the estimates of available surface areas should be investigated in the future. The atmospheric chemistry community is actively investigating possible HONO sources and it is likely that additional HONO sources, will be identified in the future. When these additional HONO sources are known, the impact of HONO chemistry on air quality in PRD can be reevaluated. 
TABLE 3: The largest enhancement in morning ( 8 am-noon) $\mathrm{O}_{3}$, daily maximum $\mathrm{O}_{3}$, and daily mean $\mathrm{PM}_{2.5}$ in the modeling domain due the additional HONO sources (case HONO $S / V$ subtract case CB05).

\begin{tabular}{lccc}
\hline Date & $\begin{array}{c}\text { The largest } \\
\text { enhancement } \\
\text { in morning } \\
\mathrm{O}_{3}(\mathrm{ppbV})\end{array}$ & $\begin{array}{c}\text { The largest } \\
\text { enhancement in } \\
\text { daily maximum } \\
\text { 8-hour } \mathrm{O}_{3}(\mathrm{ppbV})\end{array}$ & $\begin{array}{c}\text { The largest } \\
\text { enhancement } \\
\text { in daily } \mathrm{PM}_{10} \\
\left(\mu \mathrm{g} / \mathrm{m}^{3}\right)\end{array}$ \\
\hline Oct 22, 2004 & 4 & 4 & 4 \\
Oct 23, 2004 & 5 & 4 & 7 \\
Oct 24, 2004 & 4 & 3 & 6 \\
Oct 25, 2004 & 5 & 3 & 9 \\
Oct 26, 2004 & 3 & 3 & 6 \\
Oct 27, 2004 & 3 & 3 & 8 \\
Oct 28, 2004 & 4 & 5 & 17 \\
Oct 29, 2004 & 7 & 7 & 17 \\
Oct 30, 2004 & 6 & 6 & 6 \\
Oct 31, 2004 & 9 & 7 & 15 \\
Nov 1, 2004 & 3 & 5 & \\
\hline
\end{tabular}
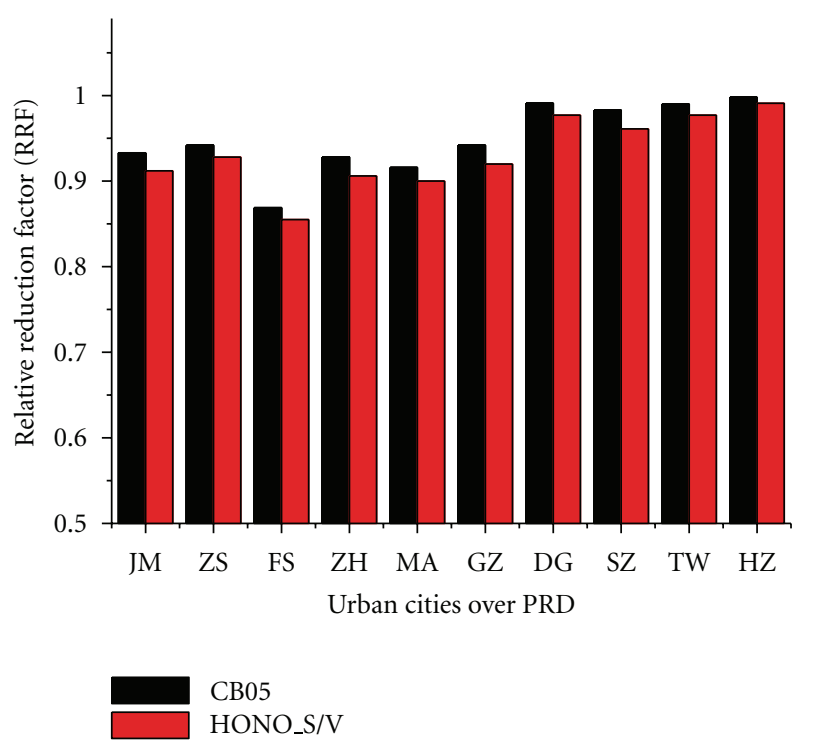

FIGURE 10: Average relative reduction factor (RRF) for ozone is due to $25 \%$ VOC emission reduction using simulation cases CB05 and HONO_S/V. The major cities over PRD are ordered by longitude from west to east (see Figure 1): JM: Jiangmen, ZS: Zhongshan, FS: Foshan, ZH: Zhuhai, Ma: Macau, GZ: Guangzhou, DG: Dongguan, SZ: Shenzhen, TW: Tsuen Wan, and HZ: Huizhou.

\section{Acknowledgments}

This project was supported by HKUST Oversea Research Grant for PhD student, Grants from the Research Grant Council of Hong Kong (RGC612807, RGC615406), and NSFC/RGC Joint Research Scheme (N_HKUST630/04, N_HKUST631/05). Although this paper has been reviewed by EPA and approved for publication, it does not necessarily reflect EPA's polices or views.

\section{References}

[1] G. W. Harris, W. P. L. Cater, A. M. Winer, J. N. Pitts, U. Platt, and D. Perner, "Observations of nitrous acid in the Los Angeles atmosphere and implications for predictions of ozoneprecursor relationships," Environmental Science Technology, vol. 16, no. 7, pp. 414-419, 1982.

[2] M. E. Jenkin, R. A. Cox, and D. J. Williams, "Laboratorystudies of the kinetics of formation of nitrous acid from the thermal reaction of nitrogen dioxide and water vapour," Atmospheric Environment, vol. 22, no. 3, pp. 487-498, 1988.

[3] A. M. Winer and H. W. Biermann, "Long pathlength differential optical absorption spectroscopy (Doas) measurements of gaseous $\mathrm{HONO}, \mathrm{NO}_{2}$ and $\mathrm{HCNO}$ in the California South Coast Air Basin," Research on Chemical Intermediates, vol. 20, no. 3-5, pp. 423-445, 1994.

[4] T. Staffelbach, A. Neftel, and L. W. Horowitz, "Photochemical oxidant formation over Southern Switzerland 2. Model results," Journal of Geophysical Research D, vol. 102, no. 19, pp. 23363-23373, 1997.

[5] B. Alicke, U. Platt, and J. Stutz, "Impact of nitrous acid photolysis on the total hydroxyl radical budget during the Limitation of Oxidant Production/Pianura Padana Produzione di Ozono study in Milan," Journal of Geophysical Research D, vol. 107, no. 22, article 8196, 2002.

[6] B. Alicke, A. Geyer, A. Hofzumahaus et al., "OH formation by HONO photolysis during the BERLIOZ experiment," Journal of Geophysical Research D, vol. 108, article 8247, 17 pages, 2003.

[7] K. Acker, D. Möller, W. Wieprecht et al., "Strong daytime production of $\mathrm{OH}$ from $\mathrm{HNO}_{2}$ at a rural mountain site," Geophysical Research Letters, vol. 33, Article ID L02809, 2006.

[8] Y. H. Zhang, H. Su, L. J. Zhong et al., "Regional ozone pollution and observation-based approach for analyzing ozoneprecursor relationship during the PRIDE-PRD2004 campaign," Atmospheric Environment, vol. 42, no. 25, pp. 62036218, 2008.

[9] Y. F. Elshorbany, R. Kurtenbach, P. Wiesen et al., "Oxidation capacity of the city air of Santiago, Chile," Atmospheric Chemistry and Physics, vol. 9, no. 6, pp. 2257-2273, 2009.

[10] K. D. Lu, Y. H. Zhang, H. Su et al., "Regional ozone pollution and key controlling factors of photochemical ozone production in Pearl River Delta during summer time," Science China Chemistry, vol. 53, no. 3, pp. 651-663, 2010.

[11] J. Kleffmann, T. Gavriloaiei, A. Hofzumahaus et al., "Daytime formation of nitrous acid: a major source of $\mathrm{OH}$ radicals in a forest," Geophysical Research Letters, vol. 32, Article ID L05818, 4 pages, 2005.

[12] X. Ren, W. H. Brune, A. Oliger et al., "OH, $\mathrm{HO}_{2}$, and $\mathrm{OH}$ reactivity during the PMTACS-NY Whiteface Mountain 2002 campaign: obervations and model comparison," Journal of Geophysical Research D, vol. 111, Article ID D10S03, 2006.

[13] J. Mao, X. Ren, S. Chen et al., "Atmospheric oxidation capacity in the summer of Houston 2006: comparison with summer measurements in other metropolitan studies," Atmospheric Environment, vol. 44, no. 33, pp. 4107-4115, 2010.

[14] J. G. Calvert, G. Yarwood, and A. M. Dunker, "An evaluation of the mechanism of nitrous acid formation in the urban atmosphere," Research on Chemical Intermediates, vol. 20, no. 3-5, pp. 463-502, 1994.

[15] G. Lammel and J. N. Cape, "Nitrous acid and nitrate in the atmosphere," Chemical Society Reviews, vol. 25, pp. 361-369, 1996. 
[16] J. Kleffmann, "Daytime sources of nitrous acid (HONO) in the atmospheric boundary layer," ChemPhysChem, vol. 8, no. 8, pp. 1137-1144, 2007.

[17] B. Aumont, F. Chervier, and S. Laval, "Contribution of HONO sources to the $\mathrm{NO}_{x} / \mathrm{HO}_{x} / \mathrm{O}_{3}$ chemistry in the polluted boundary layer," Atmospheric Environment, vol. 37, no. 4, pp. 487-498, 2003.

[18] G. Li, W. Lei, M. Zavala et al., "Impacts of HONO sources on the photochemistry in Mexico City during the MCMA2006/MILAGO Campaign," Atmospheric Chemistry and Physics, vol. 10, no. 14, pp. 6551-6567, 2010.

[19] C. Kessler and U. Platt, "Nitrous acid in polluted air massessources and formation pathways," in Physico-Chemical Behaviour of Atmospheric Pollutants (Proceedings), B. Versino and G. Angeletti, Eds., pp. 412-422, Reidel, Dordrecht, The Netherlands, 1984.

[20] R. Kurtenbach, K. H. Becker, J. A. G. Gomes et al., "Investigations of emissions and heterogeneous formation of HONO in a road traffic tunnel," Atmospheric Environment, vol. 35, no. 20, pp. 3385-3394, 2001.

[21] T. W. Kirchstetter, R. A. Harley, and D. Littlejohn, "Measurement of nitrous acid in motor vehicle exhaust," Environmental Science \& Technology, vol. 30, no. 9, pp. 2843-2849, 1996.

[22] S. Li, J. Matthews, and A. Sinha, "Atmospheric hydroxyl radical production from electronically excited $\mathrm{NO}_{2}$ and $\mathrm{H}_{2} \mathrm{O}$," Science, vol. 319, no. 5870, pp. 1657-1660, 2008.

[23] G. Sarwar, R. W. Pinder, K. W. Appel, R. Mathur, and A. G. Carlton, "Examination of the impact of photoexcited $\mathrm{NO}_{2}$ chemistry on regional air quality," Atmospheric Environment, vol. 43, no. 40, pp. 6383-6387, 2009.

[24] J. N. Crowley and S. Carl, "OH formation in the photoexcitation of $\mathrm{NO}_{2}$ beyond the dissociation threshold in the presence of water vapor," Journal of Physical Chemistry A, vol. 101, no. 23, pp. 4178-4184, 1997.

[25] S. Carr, D. E. Heard, and M. A. Blitz, "Comment on "atmospheric hydroxyl radical production from electronically excited $\mathrm{NO}_{2}$ and $\mathrm{H}_{2} \mathrm{O}$ '”' Science, vol. 324, no. 5925, p. 336, 2009.

[26] S. Li, J. Matthews, and A. Sinha, "Response to comment on 'atmospheric hydroxyl radical production from electronically excited $\mathrm{NO}_{2}$ and $\mathrm{H}_{2} \mathrm{O}$,' Science, vol. 324, no. 5925, p. 336, 2009.

[27] G. Yarwood, S. Rao, M. Yocke, and G. Whitten, "Updates to the carbon bond chemical mechanism: CB05, final report to the U.S. EPA, RT-0400675," 2005, http://www.camx.com/.

[28] I. Bejan, Y. Abd El Aal, I. Barnes et al., "The photolysis of orthonitrophenols: a new gas phase source of HONO," Physical Chemistry Chemical Physics, vol. 8, no. 17, pp. 2028-2035, 2006.

[29] R. Svensson, E. Ljungstrom, and O. Lindqvist, "Kinetics of the reaction between nitrogen dioxide and water vapour," Atmospheric Environment, vol. 21, no. 7, pp. 1529-1539, 1987.

[30] R. F. Graham and B. J. Tyler, "Formation of nitrous acid in a gas-phase stirred flow reactor," Journal of the Chemical Society, Faraday Transactions 1, vol. 68, pp. 683-688, 1972.

[31] J. Kleffmann, K. H. Becker, and P. Wiesen, "Heterogeneous $\mathrm{NO}_{2}$ conversion processes on acid surfaces: possible atmospheric implications," Atmospheric Environment, vol. 32, no. 16, pp. 2721-2729, 1998.

[32] B. J. Finlayson-Pitts, L. M. Wingen, A. L. Sumner, D. Syomin, and K. A. Ramazan, "The heterogeneous hydrolysis of $\mathrm{NO}_{2}$ in laboratory systems and in outdoor and indoor atmospheres: an integrated mechanism," Physical Chemistry Chemical Physics, vol. 5, no. 2, pp. 223-242, 2003.
[33] M. Ammann, M. Kalberer, D. T. Jost et al., "Heterogeneous production of nitrous acid on soot in polluted air masses," Nature, vol. 395, no. 6698, pp. 157-160, 1998.

[34] L. Gutzwiller, F. Arens, U. Baltensperger, H. W. Gäggeler, and M. Ammann, "Significance of semivolatile diesel exhaust organics for secondary HONO formation," Environmental Science \& Technology, vol. 36, no. 4, pp. 677-682, 2002.

[35] J. Kleffmann, K. H. Becker, M. Lackhoff, and P. Wiesen, "Heterogeneous conversion of $\mathrm{NO}_{2}$ on carbonaceous surfaces," Physical Chemistry Chemical Physics, vol. 1, no. 24, pp. 54435450, 1999.

[36] F. Arens, L. Gutzwiller, U. Baltensperger, H. W. Gäggeler, and M. Ammann, "Heterogeneous reaction of $\mathrm{NO}_{2}$ on diesel soot particles," Environmental Science \& Technology, vol. 35, no. 11, pp. 2191-2199, 2001.

[37] A. M. Rivera-Figueroa, A. L. Sumner, and B. J. Finlayson-Pitts, "Laboratory studies of potential mechanisms of renoxification of tropospheric nitric acid," Environmental Science \& Technology, vol. 37, no. 3, pp. 548-554, 2003.

[38] E. M. Knipping and D. Dabdub, "Modeling surface-mediated renoxification of the atmosphere via reaction of gaseous nitric oxide with deposited nitric acid," Atmospheric Environment, vol. 36, no. 36-37, pp. 5741-5748, 2002.

[39] K. Stemmler, M. Ammann, C. Donders, J. Kleffmann, and C. George, "Photosensitized reduction of nitrogen dioxide on humic acid as a source of nitrous acid," Nature, vol. 440, no. 7081, pp. 195-198, 2006.

[40] K. Stemmler, M. Ndour, Y. Elshorbany et al., "Light induced conversion of nitrogen dioxide into nitrous acid on submicron humic acid aerosol," Atmospheric Chemistry and Physics, vol. 7, no. 16, pp. 4237-4248, 2007.

[41] X. Zhou, K. Civerolo, H. Dai, G. Huang, J. J. Schwab, and K. L. Demerjian, "Summertime nitrous acid chemistry in the atmospheric boundary layer at a rural site in New York State," Journal of Geophysical Research D, vol. 107, no. 21, article 4590, 2002.

[42] K. A. Ramazan, D. Syomin, and B. J. Finlayson-Pitts, "The photochemical production of HONO during the heterogeneous hydrolysis of $\mathrm{NO}_{2}$," Physical Chemistry Chemical Physics, vol. 6, no. 14, pp. 3836-3843, 2004.

[43] M. E. Monge, B. D’Anna, L. Mazri et al., "Light changes the atmospheric reactivity of soot," Proceedings of the National Academy of Sciences of the United States of America, vol. 107, no. 15, pp. 6605-6609, 2010.

[44] B. Vogel, H. Vogel, J. Kleffmann, and R. Kurtenbach, "Measured and simulated vertical profiles of nitrous acid-Part II. Model simulations and indications for a photolytic source," Atmospheric Environment, vol. 37, no. 21, pp. 2957-2966, 2003.

[45] W. Lei, R. Zhang, X. Tie, and P. Hess, "Chemical characterization of ozone formation in the Houston-Galveston area: a chemical transport model study," Journal of Geophysical Research D, vol. 109, Article ID D12301, 15 pages, 2004.

[46] G. Sarwar, S. J. Roselle, R. Mathur, W. Appel, R. L. Dennis, and B. Vogel, "A comparison of CMAQ HONO predictions with observations from the Northeast Oxidant and Particle Study," Atmospheric Environment, vol. 42, no. 23, pp. 57605770, 2008.

[47] M. Gonçalves, D. Dabdub, W. L. Chang, F. Saiz, O. Jorba, and J. M. Baldasano, "The impact of different nitrous acid sources in the air quality levels of the lberian Peninsula," Atmospheric Chemistry and Physics Discussion, vol. 10, pp. 28183-28230, 2010. 
[48] M. Hu, F. M. Zhou, K. S. Shao, Y. H. Zhang, X. Y. Tang, and J. Slanina, "Diurnal variations of aerosol chemical compositions and related gaseous pollutants in Beijing and Guangzhou," Journal of Environmental Science and Health A, vol. 37, no. 4, pp. 479-488, 2002.

[49] Y. H. Zhang, M. Hu, L. J. Zhong et al., "Regional integrated experiments on air quality over Pearl River Delta 2004 (PRIDE-PRD2004): overview," Atmospheric Environment, vol. 42, no. 25, pp. 6157-6173, 2008.

[50] M. Qin, P. H. Xie, H. Su et al., "An observational study of the $\mathrm{HONO}-\mathrm{NO}_{2}$ coupling at an urban site in Guangzhou City, South China," Atmospheric Environment, vol. 43, no. 36, pp. 5731-5742, 2009.

[51] A. Hofzumahaus, F. Rohrer, K. Lu et al., "Amplified trace gas removal in the troposphere," Science, vol. 324, no. 5935, pp. 1702-1704, 2009.

[52] H. Su, Y. F. Cheng, P. Cheng et al., "Observation of nighttime nitrous acid (HONO) formation at a non-urban site during PRIDE-PRD2004 in China," Atmospheric Environment, vol. 42, no. 25, pp. 6219-6232, 2008.

[53] K. D. Lu, Y. H. Zhang, H. Su et al., "Oxidant $\left(\mathrm{O}_{3}+\mathrm{NO}_{2}\right)$ production processes and formation regimes in Beijing," Journal of Geophysical Research D, vol. 115, Article ID D07303, 18 pages, 2010.

[54] D. Byun and K. L. Schere, "Review of the governing equations, computational algorithms, and other components of the models-3 Community Multiscale Air Quality (CMAQ) modeling system," Applied Mechanics Reviews, vol. 59, no. 1-6, pp. 51-76, 2006.

[55] J. E. Pleim and J. S. Chang, "A non-local closure model for vertical mixing in the convective boundary layer," Atmospheric Environment A, vol. 26, no. 6, pp. 965-981, 1992.

[56] B. Schell, I. J. Ackermann, H. Hass, F. S. Binkowski, and A. Ebel, "Modeling the formation of secondary organic aerosol within a comprehensive air quality model system," Journal of Geophysical Research D, vol. 106, no. 22, pp. 28275-28293, 2001.

[57] A. Nenes, C. Pilinis, and S. N. Pandis, "ISORROPIA: a new thermodynamic equilibrium model for multiphase multicomponent inorganic aerosols," Aquatic Geochemistry, vol. 4, no. 1, pp. 123-152, 1998.

[58] F. S. Binkowski and S. J. Roselle, "Models-3 Community Multiscale Air Quality (CMAQ) model aerosol component 1. Model description," Journal of Geophysical Research D, vol. 108, no. 4183, 18 pages, 2003.

[59] G. A. Grell, J. Dudhia, and D. R. Stauffer, "A description of the fifth-generation Penn State/NCAR mesoscale model (MM5)," NCAR Technical Note NCAR/TN-398+STR, National Center for Atmospheric Research, Boulder, Colo, USA, 1994.

[60] S. H. L. Yim, J. C. H. Fung, A. K. H. Lau, and S. C. Kot, "Developing a high-resolution wind map for a complex terrain with a coupled MM5/CALMET system," Journal of Geophysical Research D, vol. 112, no. 5, Article ID D05106, 2007.

[61] J. C. F. Lo, A. K. H. Lau, J. C. H. Fung, and F. Chen, "Investigation of enhanced cross-city transport and trapping of air pollutants by costal and urban land-sea breeze circulations," Journal of Geophysical Research, vol. 111, Article ID D14104, 2006.

[62] X. Lu, K. C. Chow, T. Yao, J. C. H. Fung, and A. K. H. Lau, "Seasonal variation of the land-sea breeze circulation in the Pearl River Delta region," Journal of Geophysical Research D, vol. 114, no. 17, Article ID D17112, 2009.
[63] J. P. Huang, J. C. H. Fung, and A. K. H. Lau, "Integrated processes analysis and systematic meteorological classification of ozone episodes in Hong Kong," Journal of Geophysical Research D, vol. 111, Article ID D20309, 14 pages, 2006.

[64] R. H. F. Kwok, J. C. H. Fung, A. K. H. Lau, and J. S. Fu, "Numerical study on seasonal variations of gaseous pollutants and particulate matters in Hong Kong and Pearl River Delta region," Journal of Geophysical Research D, vol. 115, Article ID D16308, 2010.

[65] M. R. Houyoux, J. M. Vukovich, C. J. Coats Jr., N. M. Wheeler, and P. S. Kasibhatla, "Emission inventory development and processing for the seasonal model for regional air quality (SMRAQ) project," Journal of Geophysical Research D, vol. 105, no. 7, pp. 9079-9090, 2000.

[66] CH2M HILL (China) Limited, "Study of air quality in the Pearl River Delta region, technique report (Agreement No. CE 106/98) prepared for the Hong Kong Environmental Protection Department," Hong Kong Administrative Region Government, 2011, http://www.epd.gov.hk/epd/english/environmentinhk/air/studyrpts/study_pearl.html.

[67] USEPA, “SPECIATE data base V3.1," Research Triangle Park, NC, US, 2000, http://www.epa.gov/ttn/chief/software/speciate/speciate $32 . \mathrm{html}$.

[68] J. E. Pleim and A. Xiu, "Development and testing of a surface flux and planetary boundary layer model for application in mesoscale models," Journal of Applied Meteorology, vol. 34, no. 1, pp. 16-32, 1995.

[69] M. R. Jones, Ammonia deposition to semi-natural vegetation [Ph.D. dissertation], University of Dundee, Scotland, UK, 2006.

[70] C. X. Cai, Implementation and performance evaluation on an air quality forecast modeling system (AQFMS) for northeastern USA [Ph.D. dissertation], Department of Earth and Atmospheric Science, University at Albany, State University of New York, Albany, NY, USA, 2005.

[71] X. L. Zhou, H. L. Gao, Y. He et al., "Nitric acid photolysis on surfaces in low- $\mathrm{NO}_{x}$ environments: significant atmospheric implications," Geophysical Research Letters, vol. 30, no. 2217, 4 pages, 2003.

[72] S. J. Fan, B. M. Wang, M. Tesche et al., "Meteorological conditions and structures of atmospheric boundary layer in October 2004 over Pearl River Delta area," Atmospheric Environment, vol. 42, no. 25, pp. 6174-6186, 2008.

[73] C. J. Willmott, "On the validation of models," Physical Geography, vol. 2, no. 2, pp. 184-194, 1981.

[74] USEPA, "Guidance on the use of models and other analyses in attainment demonstrations for the 8-hour ozone NAAQS," EPA-454/R-99-004, U.S. Environmental Protection Agency, Research Triangle Park, NC, US, 1999.

[75] J. Z. Yu, X. F. Huang, J. Xu, and M. Hu, "When aerosol sulfate goes up, so does oxalate: implication for the formation mechanisms of oxalate," Environmental Science \& Technology, vol. 39, no. 1, pp. 128-133, 2005.

[76] J. Zheng, L. Zhang, W. Che, Z. Zheng, and S. Yin, "A highly resolved temporal and spatial air pollutant emission inventory for the Pearl River Delta region, China and its uncertainty assessment," Atmospheric Environment, vol. 43, no. 32, pp. 5112-5122, 2009.

[77] HKEPD (Hong Kong Environmental Protection Department), "Guideline on modeling vehicle emissions," July 2005, http:// www.epd.gov.hk/epd/english/environmentinhk/air/guide_ref/ files/EMFAC_HK_Guidelines_on_Modelling_Vehicle_Emissions_July2005.pdf. 
[78] HKPD (Hong Kong Planning Department), "Hong Kong 2030: planning vision and strategy consultancy study to analyze broad land use pattern of the Pearl River Delta Region,” 2003, http://www.pland.gov.hk/pland_en/p_study/ comp_s/hk2030/eng/consultants/pdf/Tpaper5.pdf. 

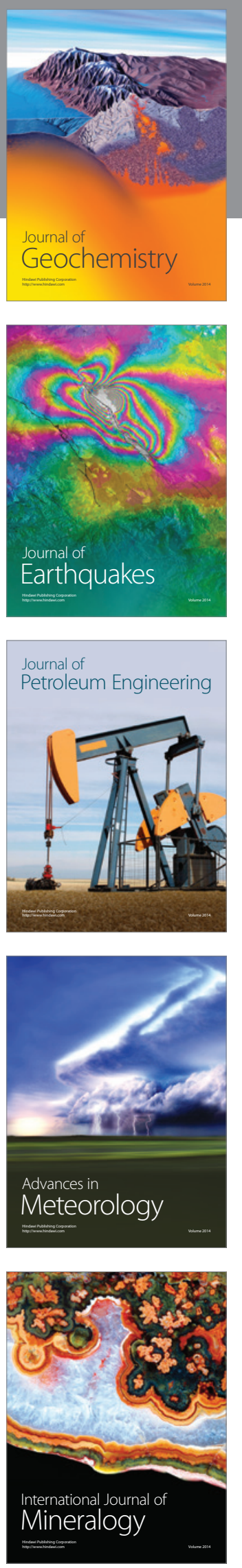
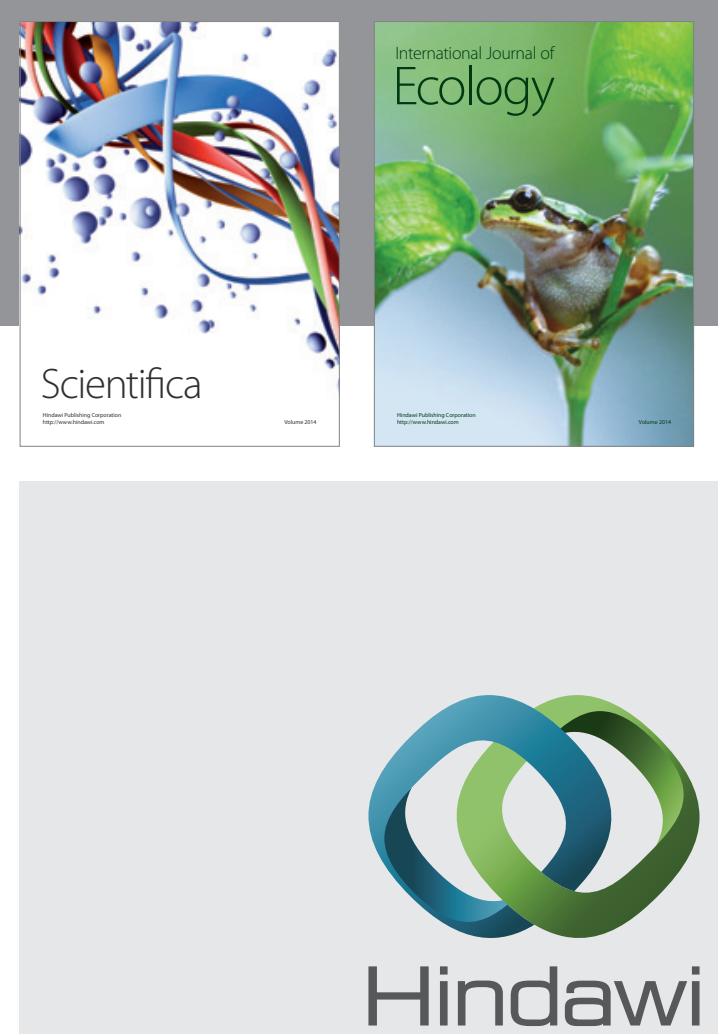

Submit your manuscripts at http://www.hindawi.com
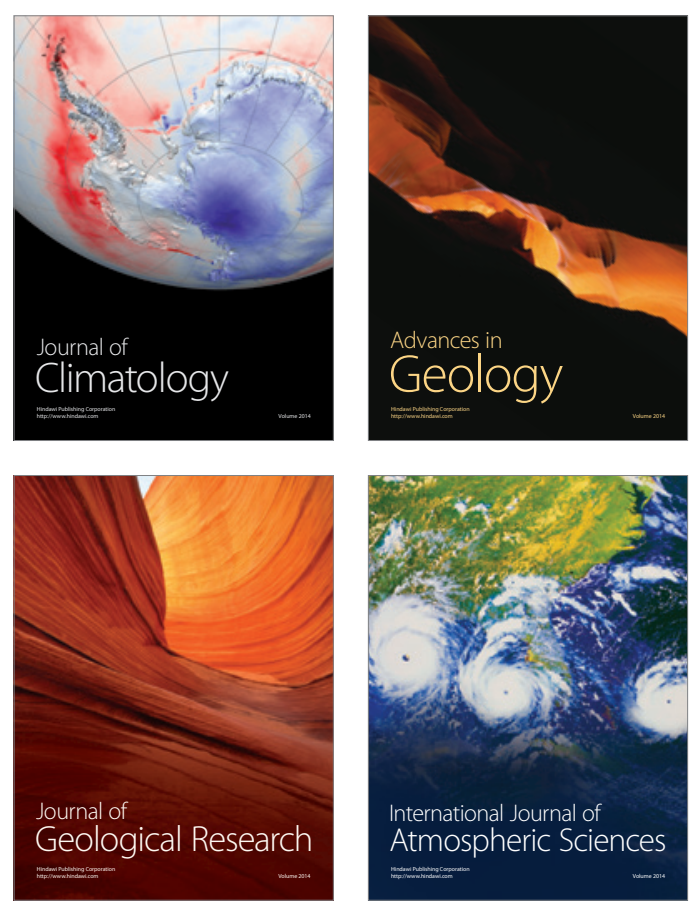
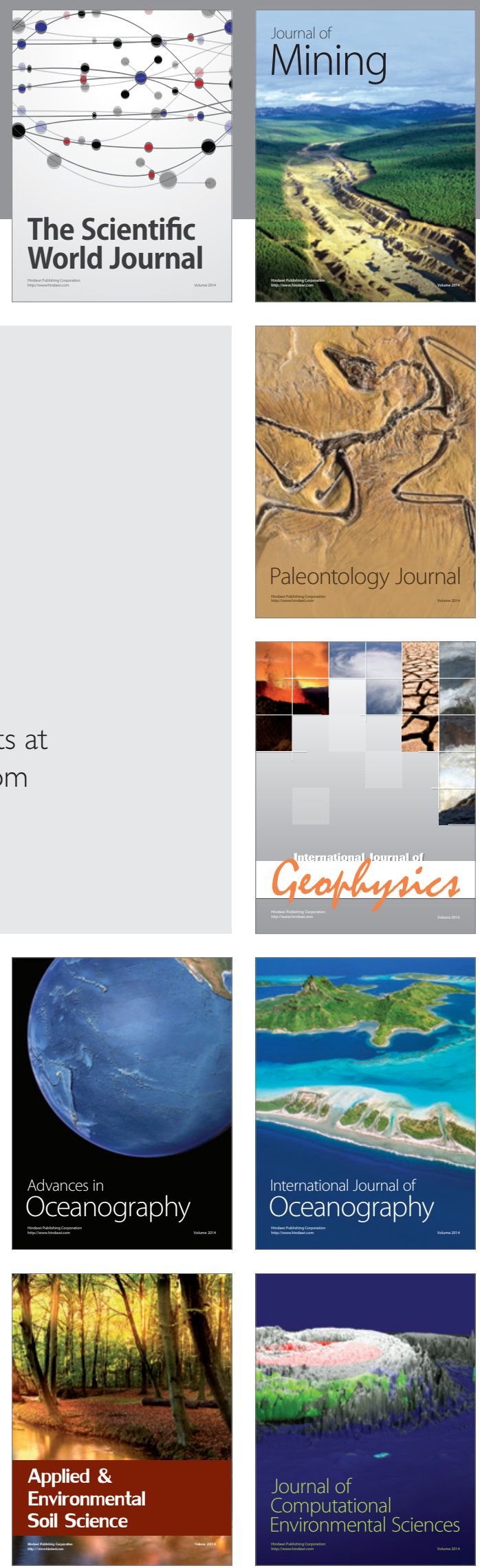